\title{
Influence of physical and biological mesoscale dynamics on the seasonal distribution and behavior of Euphausia superba in the antarctic marginal ice zone
}

\author{
Kendra L. Daly ${ }^{1, *}$, Michael C. Macaulay ${ }^{2}$ \\ ${ }^{1}$ School of Oceanography, University of Washington, Seattle, Washington 98195, USA \\ ${ }^{2}$ Applied Physics Laboratory, University of Washington, Seattle, Washington 98195, USA
}

\begin{abstract}
The influence of day length, currents, sea ice presence, seawater temperature and salinity, chlorophyll $a$, particulate organic carbon, and predators was investigated in relation to the distribution and behavior of life history stages of Euphausia superba Dana in the marginal ice zone of the Weddell and Scotia Seas during autumn, winter, and spring. Physical processes control the extent of ice cover, the magnitude and location of food, and the distribution of pack ice predators; however, physical processes did not appear to directly affect krill. Instead, the seasonal distribution and behavior of krill was interpreted to be a function of the need to acquire food and avoid predators. These 2 factors also are hypothesized to be the proximate cause of swarming during our study. Seasonal sea ice plays an integral role in the ecology of krill. Ice-edge blooms are an important and predictable food supply, particularly for reproducing adults and first-feeding larvae. Ice floes provide protection for larvae and juveniles, and sea ice biota, a widespread food source, are important to the survival of larvae during winter. In the marginal ice zone, overwintering strategies of adults included regression to an immature (sub-adult) stage, reduction of metabolic rate, and omnivorous feeding in the water column. Adults were not observed feeding on the undersurface of ice floes probably because of increased risk of predation from pack ice predators. However, adult krill may migrate deeper into the pack ice in winter and also feed on ice biota. We conclude that sea ice biota act as a stabilizing mechanism against extreme seasonal oscillations of food supply for overwintering krill, thus contributing to the persistence of populations of E. superba.
\end{abstract}

\section{INTRODUCTION}

The relative importance of physical and biological mechanisms regulating marine plankton communities is being debated (e.g. Landry 1977, Steele \& Frost 1977, Sissenwine 1984, Mackas et al. 1985, Gliwicz \& Pijanowska 1990). Spatial heterogeneity, population structure, and abundance variability are affected by physical factors, resource limitation, and predation. Planktonic organisms must be able to survive and reproduce in an environment where food, competitors, reproductively active individuals, and predators also have heterogeneous distributions. Relating spatial

- Present address: Graduate Program in Ecology, University of Tennessee, Knoxville, Tennessee 37996, USA patterns of populations and communities to the underlying processes governing their formation is a major goal of ecologists.

In the Southern Ocean the antarctic krill, Euphausia superba, is the dominant member of the ecosystem in many areas and plays a key role in the food web as a major link in the transfer of energy between primary producers and predator populations of fish, birds, squid, seals, and whales (Laws 1985). In 1961, a trawl fishery for krill was established. Concern that overfishing might adversely affect the antarctic ecosystem has emphasized the need for improved knowledge of the ecology, biomass, behavior, and distribution of E. superba, although present annual landings are

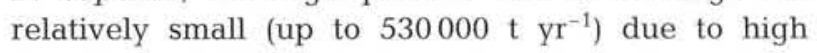
operating costs (Sahrhage 1989). 
The physical-biological interactions affecting krill populations are not well documented (Sahrhage 1988), and their effect on the distribution of Euphausia superba depends on the spatial scales considered. Krill have a circumpolar distribution, influenced by largescale circulation features, such as the Antarctic Circumpolar Current and the large gyres (Amos 1984). Although they are more concentrated in some areas of the Southern Ocean, there is no evidence to suggest that krill form separate stocks (MacDonald et al. 1986, Fevolden \& Schneppenheim 1988). Their northern distribution extends to the Antarctic Polar Front, but knowledge of their distribution in southern regions has been limited because of the seasonal pack ice.

On a regional scale, the largest known concentrations of krill and the primary nursery area for larval krill are in the vicinity of the Antarctic Peninsula and in the confluence of currents from the Weddell and Scotia Seas (Amos 1984, Brinton \& Townsend 1984). Even though most data have been collected in this area, accumulating evidence indicates that this concentration is real and not an artifact of sampling bias (Priddle et al. 1988). Large interannual differences in abundance have been observed in this region (Heywood et al. 1985, Brinton et al. 1987), yet recent evidence suggests that these differences were due to mesoscale variations in distribution in response to environmental changes (e.g. interannual variations in the position of the Weddell-Scotia Confluence; Priddle et al. 1988).

Like most zooplankton, larval krill are subject to dispersing currents and changing physical-biological conditions. Adults, however, are strong swimmers, sustaining speeds of 15 to $20 \mathrm{~cm} \mathrm{~s}^{-1}$ (Kanda et al. 1982, Hamner 1984), and capable of abandoning suboptimal environments and aggregating over large vertical and horizontal distances in favorable areas, such as frontal zones (e.g. Weddell-Scotia Confluence) and along ice edges (Mackintosh 1972), in regions of high current shear (Witek et al. 1988), and over shelf slopes (Macaulay et al. 1984, Stein \& Rakusa-Suszczewski 1984).

Few studies have demonstrated a clear relationship between environmental factors and krill. For example, temperature, salinity, and oxygen were not found to influence the distribution of krill swarms (Witek et al. 1981, Weber et al. 1986) and no correlation was found between latitude, seawater density and stability, dissolved organic matter, or nutrient concentrations and krill density (Weber \& El-Sayed 1985). Euphausia superba is well adapted to the narrow range of seawater temperatures $\left(-1.8\right.$ to $\left.2^{\circ} \mathrm{C}\right)$ typical of the Southern Ocean (Aarset \& Torres 1989); thus temperature may not be a dominant factor controlling the distribution of krill within its geographic range. Temperature, however, does influence growth and developmental rates (Ikeda \& Dixon 1982a, Ross et al. 1988) and thus may affect spatial patterns of biomass and population structure.

The geographic location of food must affect the spatial patterns and behavior of krill. Chlorophyll distribution is highly patchy; highest concentrations are in coastal regions, frontal zones, and the marginal ice zone, while concentrations in the open ocean are similar to those in oligotrophic regions (Sakshaug \& Holm-Hansen 1984, Smith \& Sakshaug 1990). Throughout the Southern Ocean, the average chlorophyll a concentration is low $\left(0.4 \mathrm{mg} \mathrm{m}^{-3}\right.$; Holm-Hansen et al. 1989) but local concentrations may reach up to $30 \mathrm{mg} \mathrm{m}^{-3}$ (Holm-Hansen et al. 1989, Nelson et al. 1989). The primary physical factor affecting the accumulation of phytoplankton biomass is light intensity, which is a function of seasonal solar radiation, extent of ice cover, and depth of vertical mixing. In addition, low seawater temperatures limit specific growth rates of phytoplankton while nutrients rarely limit growth (Smith \& Sakshaug 1990).

Although food availability must influence the distribution of krill, it is not known whether starvation regulates krill populations. When phytoplankton concentrations are low all stages of krill feed omnivorously (Hopkins \& Torres 1989, Daly 1990); as a result chlorophyll concentration may not always be the best indicator of food availability. Furthermore, adults can live for up to 7 mo without food by utilizing their own lipids and protein and shrinking in size (Ikeda \& Dixon 1982b). Nevertheless, field data and laboratory experiments suggest that growth of krill may be food-limited, particularly in open ocean regions (Brinton \& Townsend 1984, Ikeda \& Thomas 1987). Experimental evidence also indicates that first-feeding larvae do not survive delayed food availability (Ikeda 1984, Ross \& Quetin 1989) and that food availability affects the timing of reproduction in adults and the number of batches of eggs spawned in a season (Ross \& Quetin 1986), but the implications of resource limitation to krill populations remain to be verified.

Both positive and negative correlations between food availability and krill distribution have been reported. Co-occurrence of high krill abundances and low chlorophyll concentrations has been found most frequently for discrete data (Rakusa-Suszczewski 1982, Brinton \& Townsend 1984, Nast \& Gieskes 1986). However, Weber \& El-Sayed (1985) and Weber et al. (1986), using continuous profiles of in vivo fluorescence and acoustic estimates of krill biomass, found the relationship between food and krill was dependent on the spatial scale and the variable investigated. For example, phytoplankton biomass was negatively correlated with high integrated krill density and increased number of krill swarms but was positively 
correlated with individual swarms of high biomass. Spectral power analysis of these data also suggested a positive coherence between phytoplankton and krill biomass for the 2 to $20 \mathrm{~km}$ sampling resolution.

Predation also must affect the distribution and behavior of krill since predation is considered to be the main cause of mortality in plankton populations (Sissenwine 1984, Gliwicz \& Pijanowska 1990). Krill consumption by predators is well known (reviewed in Miller \& Hampton 1989) but there is no experimental evidence for population control by predation and little is known about krill-predator interactions (Croxall et al. 1985).

In addition, social behavior may influence the distribution of krill. The trawl fishery largely is based on the swarming behavior of Euphausia superba in summer; therefore, it is important to be able to predict the formation and distribution of krill swarms. Swarms generally are tens of meters long and high (Kalinowski \& Witek 1985) but superswarms (several km long and up to $250 \mathrm{~m}$ high) have been reported over shelf slopes adjacent to the Antarctic Peninsula (Macaulay et al. 1984). Even though krill swarms are common, E. superba are facultative swarmers and may engage in other behaviors. For example, krill may disperse, form large layers, vertically migrate, swarm during the day and disperse at night, or exhibit a combination of these behaviors (Miller \& Hampton 1989).

Swarming is assumed to be a response to environmental interactions, yet little is known about motivating factors or seasonal patterns in krill behavior. Euphausia superba are sensitive to variation in food availability (Hamner et al. 1983) and changes in risk of predation (Hamner 1984, O'Brien 1987b). In one experimental study, the structure of krill swarms did not appear to change in response to water flow but rather to behaviorally induced mechanisms, such as food and predators (O'Brien 1989). In another study, krill were induced to swarm in a tank when a model of a predator was introduced (Strand \& Hamner 1990). Divers have observed complex schooling behavior in all life history stages of E. superba, including foraging, feeding, predator avoidance, and mating behavior (Hamner 1984, Naito et al. 1986, O'Brien 1987b, Hamner et al. 1989). Furthermore, a large swarm repeatedly fished by trawlers remained coherent and was observed to migrate over $187 \mathrm{~km}$ in $18 \mathrm{~d}$ (Kanda et al. 1982). Therefore, on a local scale, the formation and distribution of individual swarms are not the result of passive mechanisms, such as currents, but are behaviorally determined.

Extreme seasonal changes in daily irradiance, ice cover, and primary production strongly influence polar marine ecosystems. The maximum extent of sea ice is interannually variable (Zwally et al. 1983a); however, in general, antarctic sea ice covers about 20 million $\mathrm{km}^{2}$ in austral winter (September), and during austral summer (February) the ice recedes to about 4 million $\mathrm{km}^{2}$, or almost to the Antarctic continent, except in the western Weddell and Bellingshausen-Amundsen Seas. The 16 million $\mathrm{km}^{2}$ of sea surface covered and uncovered by ice seasonally includes most of the ocean inhabited by Euphausia superba (Marr 1962).

The marginal ice zone, defined as the region of transition from totally ice-covered water to open water uninfluenced by ice melt, is the major site of primary and new production in the Southern Ocean (Smith \& Nelson 1986, 1990). Marginal ice zones also are recognized as sites of enhanced biological activity and standing stocks at all trophic levels (McRoy et al. 1972, Bradstreet \& Cross 1982). Enhanced phytoplankton biomass has been observed at the ice edge relative to areas uninfluenced by ice during all seasons (Smith \& Nelson 1985, Dieckmann 1987, Nelson et al. 1987, 1989), and thus is a predictable source of food for grazers. The accumulation of phytoplankton at the ice edge is primarily a result of vertical stratification of the water column induced by low-density seawater from melting ice (Smith \& Sakshaug 1990). Chlorophyll concentrations under the ice are low compared to those in open water due to attenuated light.

Early expeditions to the Antarctic reported the association of young Euphausia superba with the ice edge (Fraser 1936, Marr 1962, Mackintosh 1972, 1973), although it was not known if these krill were specifically associated with the ice or whether their habitat was covered seasonally by ice. More recent investigations also have reported krill near the ice edge (Nast 1982, Stepien 1982) and some (Guzman 1983, Hamner et al. 1983) suggested that krill were feeding on ice algae. Sea ice biota, composed of ice algae, protozoans, and small metazoans, have been shown to be abundant and widely distributed in the seasonal pack ice (Clarke \& Ackley 1984, Hoshiai 1985, Garrison \& Buck 1989a). Thus, the extensive coverage of sea ice in winter augments the availability of food during a time of year which otherwise would be unproductive.

In spring 1983, a multidisciplinary program (AMERIEZ: Antarctic Marine Ecosystem Research at the Ice Edge Zone) began investigating the influence of the marginal ice zone on the seasonal dynamics of the food web, followed by investigations during autumn 1986 and winter 1988. The marginal ice zone exhibits strong physical and biological spatial gradients, thereby providing a site in which to observe in situ the changing patterns of natural communities in response to a transitional environment. As one component of AMERIEZ, we studied the seasonal distribution and behavior of Euphausia superba in the Weddell and Scotia Seas. Our initial results indicated 
that juvenile krill were more abundant under pack ice than in open water in spring (Daly \& Macaulay 1988) and that ice biota were an important food source for larval krill in winter (Daly 1990).

Numerous additional reports of krill associated with ice (Kawaguchi et al. 1986, Naganobu \& Komaki 1986, Hosie \& Stolp 1989, Ichii 1990) and of krill feeding on ice algae at the ice edge (Stretch et al. 1988, Hamner et al. 1989, Siegel et al. 1990), deep in the pack ice, or under fast ice (Spiridonov et al. 1985, O'Brien 1987a, Marschall 1988, Ikeda \& Kirkwood 1989) indicate that the association between krill and sea ice is common in the Southern Ocean. Yet, little is known about the physical, chemical, and biological dynamics that generate structure and spatial patterns in krill populations in the ice edge ecosystem. In the present work, we examine the relationships between the spatial distributions of ice cover, temperature, salinity, food availability, and life history stages of Euphausia superba during autumn, winter, and spring in order to develop an understanding of the processes governing krill populations. In addition, some aspects of the behavior of krill also are described. The results of this study are integrated with currently available information to develop a mechanistic life history model for E. superba in relation to seasonal sea ice.

\section{MATERIALS AND METHODS}

Study areas. The marginal ice zones of the Weddell and Scotia Seas were surveyed in spring 1983, early autumn 1986, and winter 1988, the locations dependent on the advancing or retreating seasonal ice pack (Fig. 1). We assumed that seasonal factors and not location or year had the greatest impact on krill populations near the ice edge. Larvae recruit in summer, and therefore seasonal changes in age- 0 larvae are most easily followed from autumn to spring; hence the methods and results are reported in this seasonal order.

Autumn: Field observations were made from the US Coast Guard icebreaker 'Glacier' in the pack ice and the RV 'Melville' in adjacent open water from 7 to 27 March 1986 (Fig. 1A). The study area was located in the northwestern Weddell Sea, off the shelf in deep water ( 3000 to $4000 \mathrm{~m}$ ). Physical conditions, nutrient fields, and phytoplankton biomass were described by Nelson et al. (1989). The ice edge was well defined and remained almost stationary during the study. The pack ice, consisting primarily of first-year and multi-year ice floes, was consolidated. The water column was characterized by a well-mixed surface layer and a pronounced pycnocline between 25 to $30 \mathrm{~m}$, increasing to
$50 \mathrm{~m}$ depth in open water. Currents from large-scale circulation of the Weddell Gyre were barely measurable based on geopotential surface heights above 500 or $1500 \mathrm{~dB}$ levels.

Winter: Ice and open water stations were surveyed by the RV 'Polar Duke' from 9 June to 5 July 1988 (Leg 1) and 18 July to 14 August 1988 (Leg 2) (Fig. 1B). During Leg 1, stations were concentrated in the pack ice and during Leg 2 ice edge and open water sampling were emphasized. The study area incorporated the shallow shelf areas (650 to $1000 \mathrm{~m}$ ) (Stns 1 to 7 and 31 to 41) of the South Scotia ridge, including the South Orkney Islands, at the northern boundary of the Weddell Sea and the deeper Scotia Basin (3000 to $4000 \mathrm{~m})$. The physical oceanography was described by Muench et al. (1990). There was a net ice advance of about $200 \mathrm{~km}$ during the survey period, primarily from young ice and first-year floes. However, the position of the ice edge fluctuated up to $100 \mathrm{~km}$ within a few days due to advection and freezing/ thawing events. Multi-year pack ice was located at the southern part of the survey area, particularly in shoal areas to the west of the South Orkney Islands. Most of the stations were located in the southern central Scotia Sea, a region of mixing between Weddell and Scotia seawater; only the southernmost stations on Leg 1 were in Weddell water. The mixed layer varied from 80 to $140 \mathrm{~m}$ in depth. Currents generally were eastward with speeds of 5 to $10 \mathrm{~cm} \mathrm{~s}^{-1}$, and several large eddies were documented.

Spring: Data were collected aboard the US Coast Guard icebreaker 'Westwind' in the pack ice and the RV 'Melville' in open water from 11 November to 2 December 1983 (Fig. 1C). The spring study area also was located at the interface of the Weddell and Scotia Seas but all stations were to the east of the South Orkney Islands in water 1000 to $4000 \mathrm{~m}$ deep. Physical oceanography, nutrients, and phytoplankton distributions were described by Nelson et al. (1987). Three basic water types were defined: (1) north of $59^{\circ} \mathrm{S}$, Drake Passage-Scotia Sea water $\left(\mathrm{T}>0{ }^{\circ} \mathrm{C}\right.$; $\mathrm{S} \approx 33.95$ to $34.10 \%$ ), (2) ca $61^{\circ} \mathrm{S}$ to $59^{\circ} \mathrm{S}$, Weddell-Scotia Confluence $\left(\mathrm{T}<-1{ }^{\circ} \mathrm{C} ; \mathrm{S}<34.35 \%\right.$ ); and (3) cold, but more saline Weddell seawater $\left(\mathrm{T}<-1{ }^{\circ} \mathrm{C} ; \mathrm{S}>34.35 \%\right.$ ) under the ice on the western side of the study area diagonally extending to just north of the ice edge on the eastern side. The ice edge was characterized by diffuse bands of ice and was rapidly retreating (ca $5.2 \mathrm{~km} \mathrm{~d}^{-1}$ ). Leads and large polynyas occurred in the pack ice, which was predominately first-year ice floes. The mixed layer depth was variable (50 to $140 \mathrm{~m}$ under the ice and 30 to $80 \mathrm{~m}$ in open water). Current speed and direction were not determined but were assumed to be similar to those measured in winter. 
Fig. 1. Location of study areas in (A) autumn, (B) winter, and (C) spring; arrows indicate direction of currents in the Weddell-Scotia Confluence; contour is the $500 \mathrm{~m}$ isobath of the shelf edge near the Antarctic Peninsula and South Orkney Islands. Symbols on (A), (B), and (C) represent hydrographic stations and net tows (numbers); open and filled symbols in (A) and (C) indicate ships used, and in (B) indicate Legs 1 and 2; dashed lines denote approximate location of ice edge in (A) and (C) and minimum and maximum location of ice edge in (B)

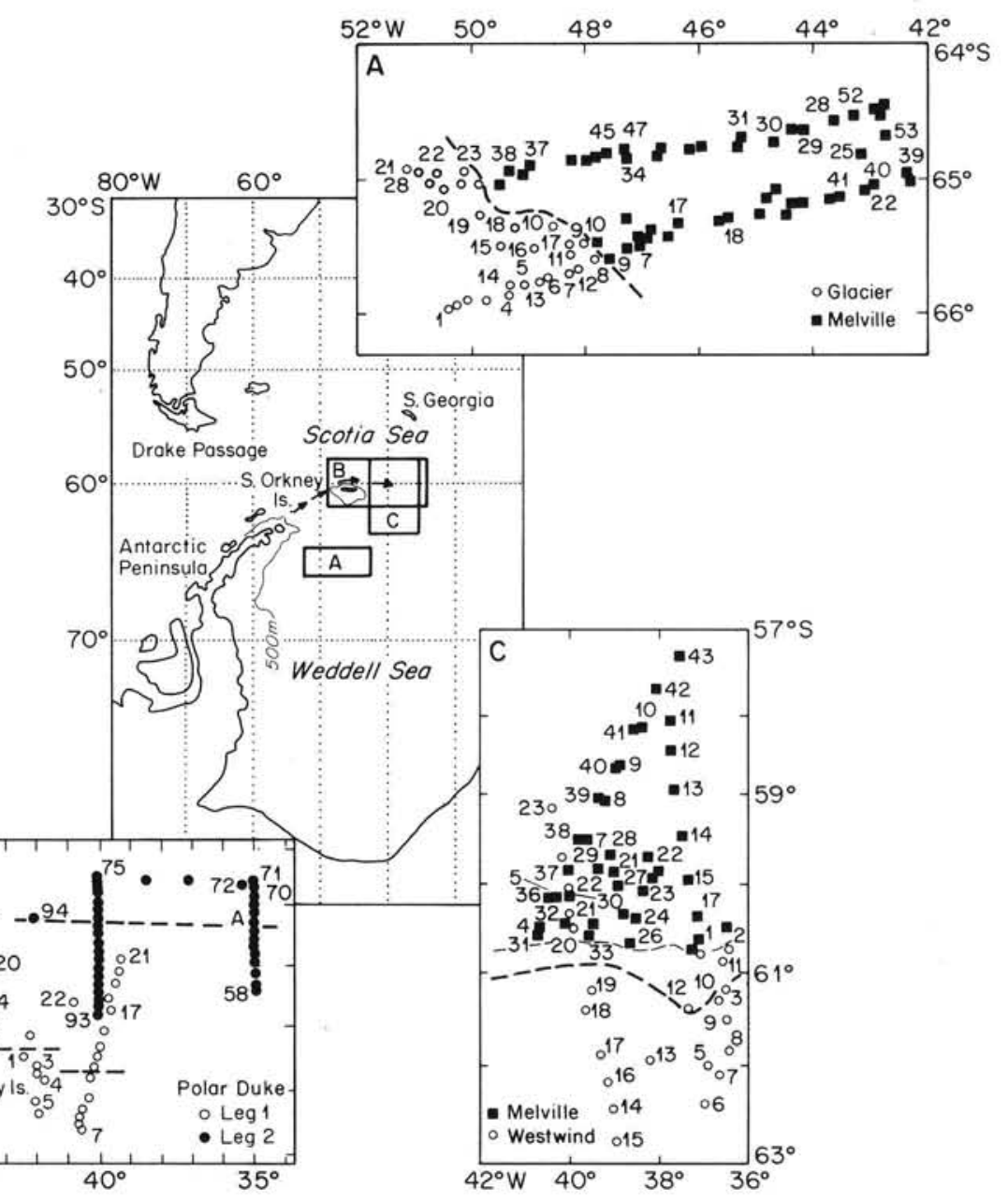

Field methods. During each season, temperature, salinity, chlorophyll $a$, and particulate organic carbon (POC) samples were collected at all hydrographic stations, as described by Nelson et al. $(1987,1989)$ and Muench et al. (1990). Krill samples were collected by a variety of methods. In addition to our plummet net collections, other AMERIEZ investigators provided Tucker trawl, plankton, and plummet (small mesh size) net samples from under the ice and in open water in autumn and winter and Bongo net data from open water in spring, thereby providing a wide coverage of krill distribution in the marginal ice zone.

Net samples were used to determine the seasonal distribution and abundance of life history stages and size classes and the location and composition of krill swarms. Acoustic methods provided biomass estimates for the correlation analyses (autumn) and also detected the distribution and frequency of krill swarms. Net methods used in each season are described below and the equipment used is shown in Table 1. Sampling speed of all nets was $1 \mathrm{~m} \mathrm{~s}^{-1}$ and net samples were preserved in buffered 4 to $10 \%$ formaldehyde. Acoustic observations were made under the ice in autumn and spring and at all hydrographic stations in winter by lowering a transducer $1 \mathrm{~m}$ below the water surface while the ship was on station. In open water during autumn and spring, a $1.2 \mathrm{~m} \mathrm{~V}$-fin with mounted transducers was towed continuously at $6 \mathrm{~m}$ depth between stations.

Autumn: In pack ice, net sampling for krill was restricted to vertical tows with a downward-fishing, closing $1 \mathrm{~m}^{2}$ plummet net. A double tripping mechanism allowed the net to be opened and closed by messengers at predetermined depths. The downward fishing capability and lack of front bridles in this net minimized net avoidance by krill. The plummet net sampled discrete depths of 0 to $30 \mathrm{~m}$ (depth of pycnocline) and 30 to $100 \mathrm{~m}$ at all stations, 100 to $200 \mathrm{~m}$ at $70 \%$ of the stations, and 200 to $400 \mathrm{~m}$ and 400 to $1000 \mathrm{~m}$ at additional stations. Small larvae ( $<3 \mathrm{~mm}$ ) were collected with a collapsible plankton net, suspended in the mouth of an additional plummet net. In addition, Coast Guard divers provided measurements of crevices and potholes on the under- 
Table 1. Ship and equipment for each season's sampling of Euphausia superba in ice-covered and open water

\begin{tabular}{|c|c|c|}
\hline Equipment & Ice-covered & Open \\
\hline \multicolumn{3}{|l|}{ Autumn } \\
\hline Ship & 'Glacier' & 'Melville' \\
\hline \multirow[t]{2}{*}{$\begin{array}{l}\text { Net } \\
\text { (mesh size) }\end{array}$} & $\begin{array}{l}1 \mathrm{~m}^{2} \text { plummet } \\
(1.6 \mathrm{~mm})\end{array}$ & $\begin{array}{c}9 \mathrm{~m}^{2} \text { Tucker trawl } \\
(4-1 \mathrm{~mm})\end{array}$ \\
\hline & $\begin{array}{c}0.4 \mathrm{~m}^{2} \text { plankton } \\
(162 \mu \mathrm{m})\end{array}$ & $\begin{array}{c}0.4 \mathrm{~m}^{2} \text { plankton } \\
(162 \mu \mathrm{m})\end{array}$ \\
\hline $\begin{array}{l}\text { Acoustic system } \\
\text { (frequency) }\end{array}$ & $\begin{array}{l}\text { Simrad EKS } \\
(120 \mathrm{kHz})\end{array}$ & $\begin{array}{c}\text { BioSonics } \\
\text { (50 and } 120 \mathrm{kHz})\end{array}$ \\
\hline \multicolumn{3}{|l|}{ Winter } \\
\hline Ship & 'Polar Duke' & 'Polar Duke' \\
\hline \multirow[t]{4}{*}{$\begin{array}{l}\text { Net } \\
\text { (mesh size) }\end{array}$} & $\begin{array}{l}1 \mathrm{~m}^{2} \text { plummet } \\
(1.6 \mathrm{~mm})\end{array}$ & $\begin{array}{c}1 \mathrm{~m}^{2} \text { plummet } \\
(1.6 \mathrm{~mm})\end{array}$ \\
\hline & $\begin{array}{c}1 \mathrm{~m}^{2} \text { plummet } \\
(163 \mu \mathrm{m})\end{array}$ & $\begin{array}{c}1 \mathrm{~m}^{2} \text { plummet } \\
(163 \mu \mathrm{m})\end{array}$ \\
\hline & $\begin{array}{c}1.8 \mathrm{~m}^{2} \text { Tucker trawl } \\
(4-1 \mathrm{~mm})\end{array}$ & $\begin{array}{c}1.8 \mathrm{~m}^{2} \text { Tucker trawl } \\
(4-1 \mathrm{~mm})\end{array}$ \\
\hline & $\begin{array}{c}0.2 \mathrm{~m}^{2} \text { plankton } \\
(163 \mu \mathrm{m})\end{array}$ & $\begin{array}{c}0.2 \mathrm{~m}^{2} \text { plankton } \\
(163 \mu \mathrm{m})\end{array}$ \\
\hline $\begin{array}{l}\text { Acoustic system } \\
\text { (frequency) }\end{array}$ & $\begin{array}{c}\text { BioSonics } \\
(120 \text { and } 200 \mathrm{kHz})\end{array}$ & $\begin{array}{c}\text { BioSonics } \\
(120 \text { and } 200 \mathrm{kHz})\end{array}$ \\
\hline \multicolumn{3}{|l|}{ Spring } \\
\hline Ship & 'Westwind' & 'Melville' \\
\hline $\begin{array}{l}\text { Net } \\
\text { (mesh size) }\end{array}$ & $\begin{array}{c}1 \mathrm{~m}^{2} \text { plummet } \\
(560 \mu \mathrm{m})\end{array}$ & $\begin{array}{c}0.71 \mathrm{~m} \text { Bongo } \\
(333 \text { and } 505 \mu \mathrm{m})\end{array}$ \\
\hline \multirow[t]{3}{*}{$\begin{array}{l}\text { Acoustic system } \\
\text { (frequency) }\end{array}$} & $\begin{array}{l}\text { Ross 200A } \\
(105 \mathrm{kHz})\end{array}$ & $\begin{array}{l}\text { Ross 200A } \\
(105 \mathrm{kHz})\end{array}$ \\
\hline & & $\begin{array}{l}\text { Simrad EKS } \\
(120 \mathrm{kHz})\end{array}$ \\
\hline & & $\begin{array}{l}\text { BioSonics } \\
(50 \mathrm{kHz})\end{array}$ \\
\hline
\end{tabular}

surface of ice floes, estimates of nearest neighbor distances between krill, collections of juvenile krill, and underwater photographs.

In open water, large krill were collected with a modified $9 \mathrm{~m}^{2}$ opening-closing Tucker trawl and larvae were collected with a plankton net suspended in the trawl. Haul depths usually were in the upper $100 \mathrm{~m}_{i} 3$ stations were in the upper $200 \mathrm{~m}$ and selected hauls for larvae sampled as deep as $1200 \mathrm{~m}$. The Tucker trawls sampled primarily near the ice edge and along the northern transect (Fig. 1A). For further information on plankton net and trawl collections see Lancraft et al. (1989).

Winter: Owing to the rapidly fluctuating ice edge, most net stations ( $69 \%$ ) were at the ice edge or under the ice. Eleven stations were in open water at the time of sampling: Stns 17, 21, 41, 54, 56, A, 72, 75, 94, 122, and 127 (Fig. 1B). Two plummet nets were used in both the pack ice and open water for sampling continuity and they sampled discrete depths from 0 to 100,100 to 200, 200 to 400,400 to 600 , and 600 to $1000 \mathrm{~m}$ at most stations. In open water and in open leads in the ice, oblique tows were made using a modified $1.8 \mathrm{~m}^{2}$ closing Tucker trawl, with a $0.2 \mathrm{~m}^{2}$ plankton net nested within the trawl. The Tucker trawl sampled various discrete depths between 0 and $1500 \mathrm{~m}$. Additional trawl information can be obtained from Lancraft et al. (1991). Larval krill were collected from ice floes with a hand-operated diaphragm pump or a small hand-held plankton net.

Spring: In pack ice, a plummet net sampled each station from the surface to a depth determined by acoustic targets observed on echograms, typically 50 to $100 \mathrm{~m}$. Juvenile krill also were collected from the surface of ice floes overturned by the ship and were observed by divers under floes. In open water, krill were sampled by paired $0.71 \mathrm{~m}$ diameter Bongo nets in oblique tows from 0 to 200 to $0 \mathrm{~m}$ depth at every station (Brinton 1984). Bongo nets also were towed at the surface at Stns 13 and 15 for 35 and $21 \mathrm{~min}$, respectively, to describe the near-surface population structure.

Sample analyses. Methods for the analyses of temperature, salinity, chlorophyll $a$, and POC are described in Nelson et al. $(1987,1989)$ and Muench et al. (1990). Acoustic biomass in autumn was determined by methods described in Macaulay et al. (1984) and Daly \& Macaulay (1988). The acoustic systems were calibrated before and after each cruise, and temperature corrections were applied.

Euphausia superba collected by plummet net and Tucker trawls and from ice floes were identified to life history stage: calyptopis and furcilia larvae (Fraser 1936), juvenile, and immature (sub-adult) and mature adult sexual maturity stages (Makarov \& Denys 1981). Large Tucker trawl samples were subsampled with a Folsom plankton splitter to about 100 individuals; rare stages were counted for the entire sample. Length of krill was measured to the nearest $\mathrm{mm}$, from the base of the eye to the tip of the telson. Methods for Bongo net sample analyses (Brinton 1984) were similar, except krill were measured from the tip of the rostrum to the tip of the telson, adding ca 0.5 to $1 \mathrm{~mm}$ in length to the largest krill. Age of krill are reported as age- 0 for larvae and juveniles during their first year of life, age-1 for juveniles in their second year, and age-1+ for juveniles in their second and/or third year. Age cannot be determined for larger krill (or older life history stages) because adult krill may shrink in size in winter (Ikeda \& Dixon 1982b); hence, body length and age are not correlated in large krill.

Data analyses. Correlation analyses between physical, chemical, and biological variables in autumn (see Table 2) were determined by ordinary least squares linear regression (SYSTAT statistical package, 
Wilkinson 1989). Krill density on the undersurface of ice floes was determined from diver estimates of nearest neighbor distance between individuals and from underwater photographs (Nicol 1986). The seasonal depth and frequency of krill swarms were determined from acoustic echograms.

The seasonal plots of horizontal distribution of Euphausia superba include krill collected in all nets described above. To compare abundances between nets, krill catches were standardized to $1000 \mathrm{~m}^{3}$ water volume filtered. Abundance estimates from plummet nets are from the upper $100 \mathrm{~m}$ of the water column, since net and acoustic data during all seasons indicated krill occurred primarily above that depth. Krill density below $100 \mathrm{~m}$ was low and would not have changed the order of magnitude of abundance in these plots. Abundance estimates from other nets also are from the upper $100 \mathrm{~m}$, except for 3 Tucker trawls (open water in autumn; Stns 28, 3, and 45) and for Bongo nets (open water in spring), which were from the upper $200 \mathrm{~m}$. The abundance of krill at these deeper stations may be underestimated. Both shallow and deep tows may have collected krill primarily from the upper $100 \mathrm{~m}$ of the water column but deep tows filter more water, thus diluting estimates of abundance in these tows.

Abundances of krill were not normally distributed due to a small number of very large samples (i.e. swarms), thereby violating an assumption of parametric statistics. Also, the method of net collection (vertical vs oblique) was different between habitats and the catchability factor or avoidance by krill associated with each net is unknown. The intent of this study is not to focus on abundance per se but to use abundances to determine mesoscale changes in distribution; therefore, the most conservative approach was applied by reporting the median and ranges of abundance (see Tables 3, 5, \& 6) and using nonparametric statistics (Zar 1984). Tests for differences between 2 or more medians (Zar 1984) were used to compare abundance data between ice-covered and open-water locations within seasons. A $t$-test was used to compare the means of integrated chlorophyll in winter, the means of swarm frequency in spring, and the average chlorophyll and POC values in all seasons.

\section{RESULTS}

\section{Spatial distributions}

Autumn. Correlation coefficients were determined for pairs of physical, chemical, and biological variables from stations along 2 transects perpendicular to the ice edge (Table 2). Surface-layer seawater temperatures were highly correlated with distance from the ice edge, increasing from $-1.8^{\circ} \mathrm{C}$ under the ice to $-0.1^{\circ} \mathrm{C}$ at the farthest distance from the ice edge (Fig. 2A). Surface salinity varied from 33.1 to $33.8 \%$, with the lowest values near the ice edge (Fig. 2B). Food availability (chlorophyll $a$ and POC) was also highly correlated with distance from the ice edge, and thus with

Table 2. Pearson correlation matrices for physical, chemical, and biological variables along 2 transects perpendicular to the ice edge during autumn. Variables include distance from ice edge ( $\mathrm{km})$, temperature (Temp., $\left.{ }^{\circ} \mathrm{C}, 10 \mathrm{~m}\right)$, salinity $(\%, 10 \mathrm{~m})$, acoustic biomass (Biomass, $\log \mathrm{g} \mathrm{m}^{-2}$, integrated 0 to $50 \mathrm{~m}$ ), chlorophyll a ( $\mathrm{Chl} \mathrm{a}, \mathrm{mg} \mathrm{m}^{-2}$, integrated 0 to $50 \mathrm{~m}$ and 0 to $150 \mathrm{~m}$ ), particulate organic carbon (POC, $\mathrm{mg} \mathrm{m}^{-2}$, integrated 0 to $150 \mathrm{~m}$ ), and phaeopigment (Phaeo., $\mathrm{mg} \mathrm{m}^{-2}$, integrated 0 to $50 \mathrm{~m}$ ). Coefficients above 0.5 are significant $(\mathrm{p}<0.05)$

\begin{tabular}{|c|c|c|c|c|c|c|c|c|}
\hline & $\mathrm{km}$ & Temp. & Salinity & Biomass & Chl a 50 & Chl a 150 & POC & Phaeo. \\
\hline \multicolumn{9}{|c|}{ Northern transect } \\
\hline $\mathrm{km}$ & - & - & - & - & - & - & - & - \\
\hline Temp. & 0.94 & - & - & - & - & - & - & - \\
\hline Salinity & 0.69 & 0.84 & - & - & - & - & - & - \\
\hline Biomass & 0.24 & 0.37 & 0.39 & - & - & - & - & - \\
\hline Chl a 50 & 0.39 & 0.44 & 0.52 & -0.13 & - & - & - & - \\
\hline Chl a 150 & 0.68 & 0.72 & 0.71 & 0.11 & 0.89 & - & - & - \\
\hline $\mathrm{POC}$ & 0.46 & 0.35 & 0.19 & 0.33 & 0.10 & 0.32 & - & - \\
\hline Phaeo. & 0.03 & 0.02 & 0.17 & 0.13 & 0.65 & 0.63 & 0.19 & - \\
\hline \multicolumn{9}{|c|}{$\begin{array}{l}\text { Southern transect } \\
\mathrm{km}\end{array}$} \\
\hline Temp. & 0.91 & - & - & - & - & - & - & - \\
\hline Salinity & 0.01 & 0.07 & - & - & - & - & - & - \\
\hline Biomass & 0.26 & -0.03 & -0.11 & - & - & - & - & - \\
\hline Chl a 50 & 0.85 & 0.72 & 0.07 & 0.08 & - & - & - & - \\
\hline Chl a 150 & 0.89 & 0.89 & -0.00 & 0.06 & 0.92 & - & - & - \\
\hline POC & 0.90 & 0.81 & 0.04 & -0.03 & 0.92 & 0.86 & - & - \\
\hline Phaeo. & 0.79 & 0.63 & 0.04 & 0.12 & 0.98 & 0.88 & 0.87 & - \\
\hline
\end{tabular}



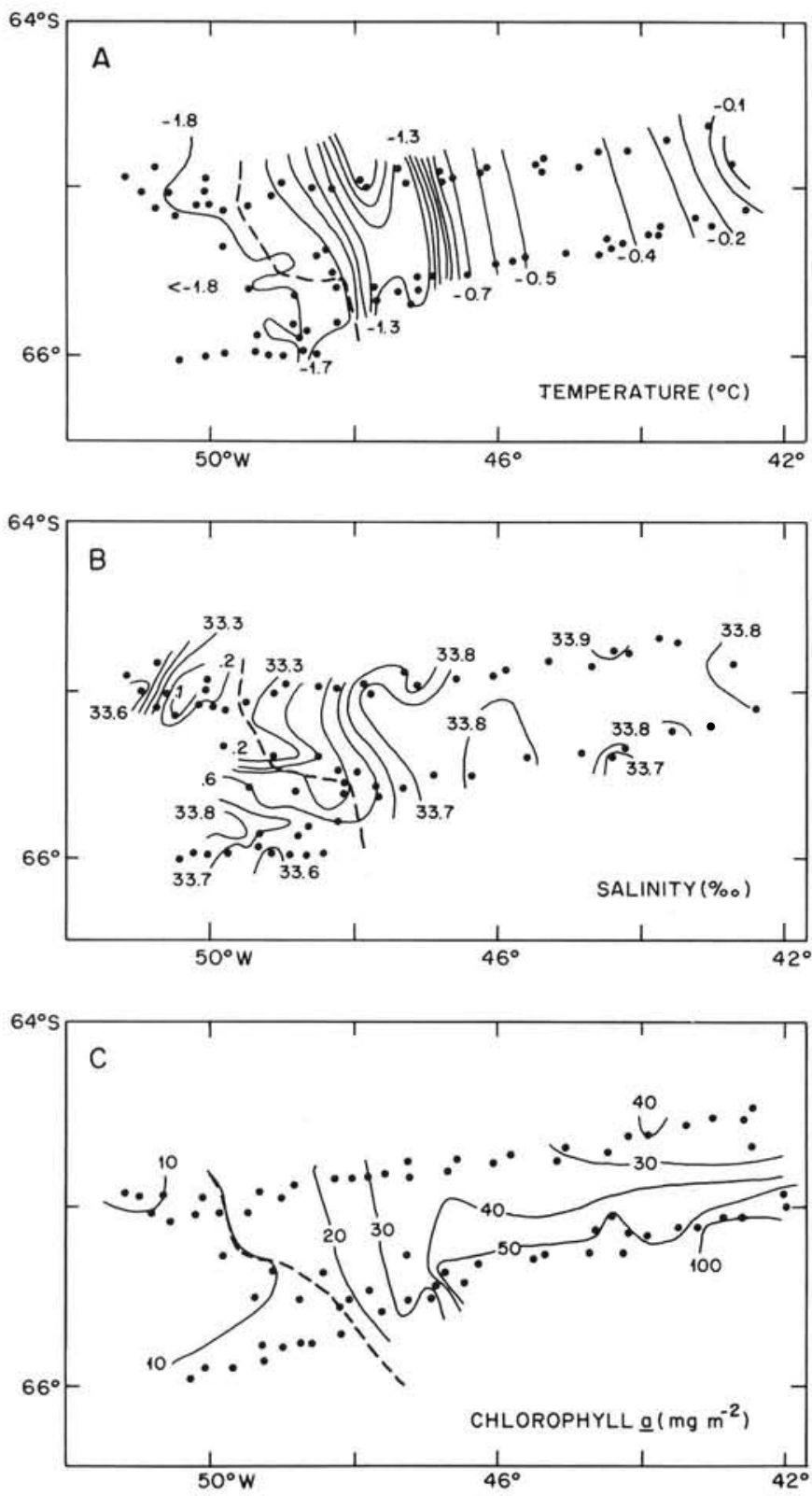

Fig. 2. Autumn horizontal distribution of environmental variables: (A) temperature and (B) salinity at $10 \mathrm{~m}$ depth, and (C) chlorophyll a integrated 0 to $150 \mathrm{~m}$. Dots represent locations of hydrographic stations. Dashed line denotes approximate location of the ice edge from 7 to 27 March 1986. [(A) and (B) from Husby \& Muench (1988); chlorophyll data from W. Smith, Jr (unpubl.)]

temperature, on the southern transect but not on the northern transect. Vertically integrated chlorophyll $a$ ( 0 to $150 \mathrm{~m}$ ) was 2 to 5 times greater in open water than under the ice (Fig. 2C), with the maximum $250 \mathrm{~km}$ seaward of the ice edge but still within the marginal ice zone. Phaeopigment, the chlorophyll degradation product of grazing, was highly correlated with chlorophyll but only weakly associated with acoustically detected krill. In fact, acoustic biomass estimates showed only weak associations with all variables.

The distribution of acoustic biomass in relation to environmental variables did not suggest physicalbiological interactions; however, the distribution of life history stages of Euphausia superba determined from net tows indicated some trends (Fig. 3). In early fall, larval krill stages included metanauplius $(7 \%)$, calyptopis 1 (92\%), which is the first-feeding stage, a few older calyptopes (C2 and 3), and furciliae (F3 and 4). In open water, most of the larvae were concentrated about 250 to $300 \mathrm{~km}$ from the ice edge in the vicinity of the chlorophyll maximum. Under the ice, larvae were concentrated at 3 stations located between $120 \mathrm{~km}$ into the pack ice and the ice edge. Juveniles also were distributed in both areas but were densest under the ice. Adults were found primarily in open water, and therefore in warmer water with higher food concentrations. Immature adults were found under the ice and in open water but were concentrated near the ice edge, whereas mature and spawning adults were collected only in open water near the ice edge. Median density of all stages was higher in open water than under the ice, but maximum densities of juveniles and immature adults occurred under the ice (Table 3). Nevertheless, densities of larvae, juveniles, or immature adults were not significantly different (median test, $p=0.05$ ) between locations.

In general, female and male krill occurred together in all samples (Fig. 3). In open water, immature females and males usually occurred together, with males dominant ( $>50 \%$ ) at $55 \%$ of the stations. Males ranged from 25 to $100 \%$ of the samples and females from 0 to $75 \%$. Under ice, immature adults were collected as isolated individuals except for one swarm (Stn 28) where males made up $55 \%$ and females $45 \%$ of the adults. Mature females and males always were found together, with females and males each dominant at half of the stations. But in all samples, proportions of females and males each varied from 33 to $66 \%$ of the mature adults.

Juvenile Euphausia superba were strongly associated with the undersurface of the pack ice at 10 out of 12 dive stations in the study area (Fig. 4). Divers observed dense concentrations of juveniles feeding on sea ice biota in potholes, brine channels, and crevices of ice floes where chlorophyll concentrations were much greater than in the underlying water. Juveniles almost never were seen more than a meter below ice floes or in open leads, and abundance (visually estimated) varied between ice floes. The largest concentrations occurred at Stns 1 and 12 and the smallest at Stns $9,10,16$, and 28. Adults rarely were seen near ice floes and no krill were observed at Stn 18 or under an iceberg at Stn 24 . 
Fig. 3. Euphausia superba. Autumn horizontal distribution of life history stages of krill. Abundance (no. per $1000 \mathrm{~m}^{3}$ ) indicated by symbol size. Larvae are predominantly age- 0 calyptopis 1 . Line denotes approximate location of ice edge, with open water to the right
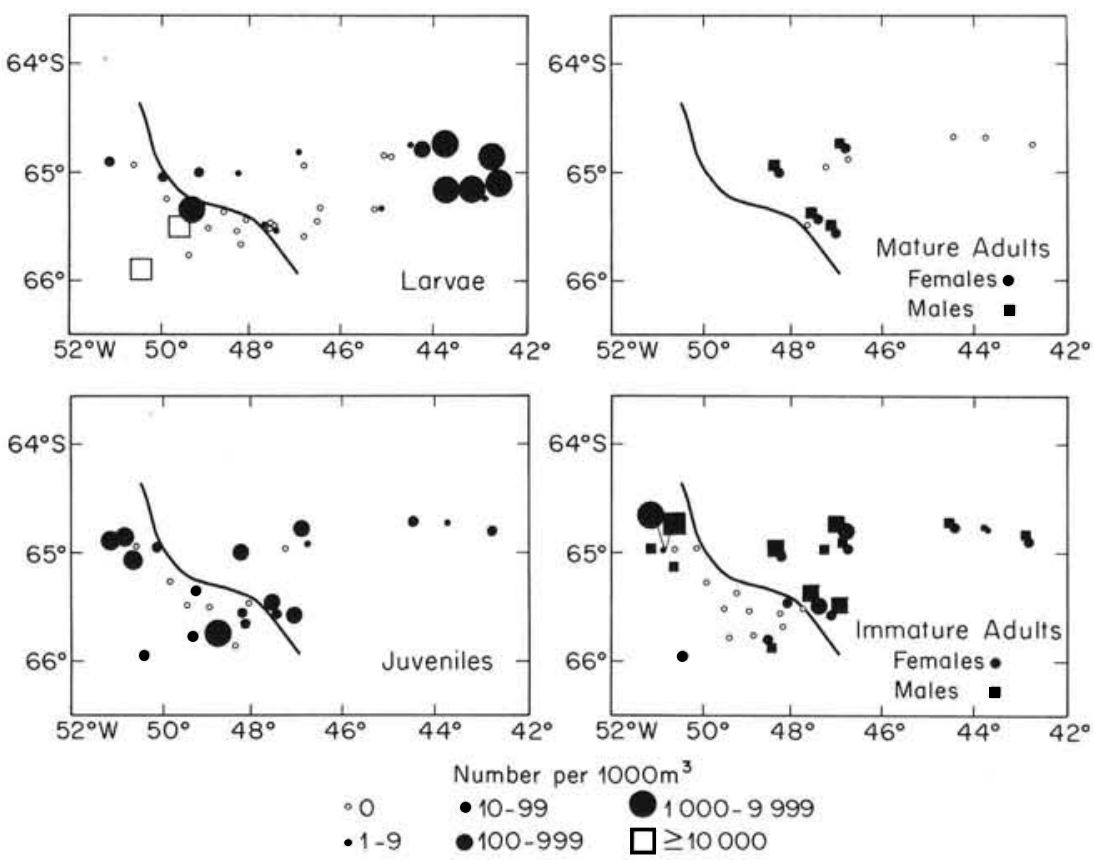

Although the juvenile component of the krill population could not be adequately assessed for the study area, divers mapped juvenile abundance and distribution (Stn 12) under one first-year ice floe, $20 \mathrm{~m}$ in diameter. The undersurface was relatively smooth with numerous potholes (ca $6.4 \times 11.4 \times 6.4 \mathrm{~cm}$ ) covering about $20 \%$ of the surface area, as well as several crevices and brine channels. Small krill were concentrated primarily in the holes in densities of ca 3000 ind. $\mathrm{m}^{-2}$. Under the hard, smooth, bottom surface of the ice floe, densities were ca 1 ind. $\mathrm{m}^{-2}$. The total number of juveniles under this floe was estimated to be 206000 individuals.

Length-frequency distributions illustrate the differences in spatial distribution of sizes of krill (Fig. 5). Only small juveniles $(\leq 25 \mathrm{~mm}$ ) were collected under ice floes, whereas both small juveniles and immature adults were found in the water column below the pack ice. Small and large juveniles, immature adults, and

Table 3. Euphausia superba. Autumn median density (no. per $1000 \mathrm{~m}^{3}$ ) and range of krill life history stages in ice-covered and open water

\begin{tabular}{|lcc|}
\hline Stage & Ice-covered & Open \\
\hline Larvae & 57 & 101 \\
Juveniles & $(10-28421)$ & $(1-5098)$ \\
& 34 & 93 \\
Immature adults & $(10-2143$ & $(5-639)$ \\
& 33 & 117 \\
Mature adults & $(10-6900)$ & $(1-425)$ \\
& - & 41 \\
& & $(28-98)$ \\
\hline
\end{tabular}

some mature and spawning adults ( 39 to $53 \mathrm{~mm}$ ) were collected in open water. Many of the large adults in our field study showed evidence of sexual regression to an immature stage for overwintering similar to that found in a laboratory study (Thomas \& Ikeda 1987).

Vertical distributions of physical, chemical, and biological variables were determined for under-ice and open-water habitats (Figs. 6 \& 7). At low temperatures, seawater density is a function of salinity distribution. Thus, the sharp vertical salinity gradient represents the stratified surface layer overlying a pronounced pycnocline at 30 to $50 \mathrm{~m}$. POC, which includes carbon from plants, animals, bacteria, and detritus, may reflect food availability more adequately than chlorophyll $a$

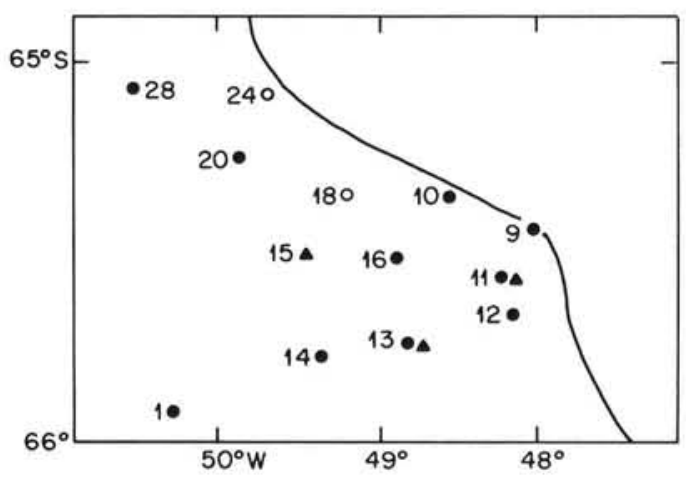

Fig. 4. Euphausia superba. Autumn horizontal distribution of juvenile krill on the undersurface of ice floes. Filled symbols indicate stations where krill were sighted underwater by divers $(\bullet)$ or from the top surface of ice floes $(\mathbf{\wedge})$. Open symbols indicate no krill sighted. Line denotes approximate location of ice edge, with open water to the right 

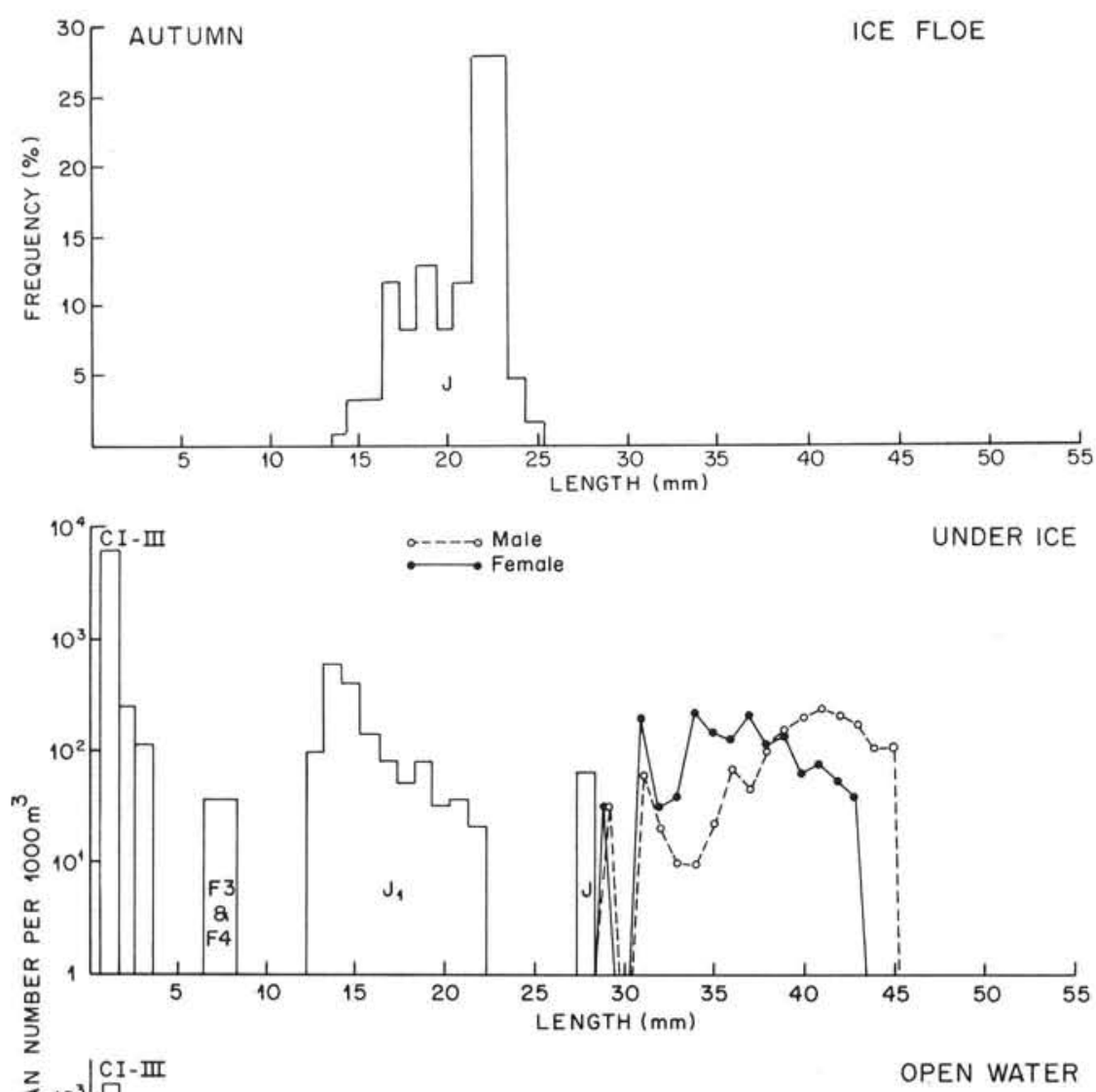

Fig. 5. Euphausia superba. Autumn length-frequency distributions of krill in relation to ice: undersurface of ice floes, water column under pack ice, and open water. $\mathrm{MN}$ : metanauplius; C: calyptopis; F: furciliae; J1: age-1+ juveniles; males and females include immature and mature adults for omnivorous krill during periods of low phytoplankton biomass. The amount of carbon contributed by phytoplankton to the POC varies greatly (e.g. the ratio observed in spring was 31.8 but in autumn was 114; Nelson et al. 1987, 1989). In autumn, phytoplankton carbon under the ice ( 3.6 to $\left.12.5 \mathrm{mg} \mathrm{C} \mathrm{m}^{-3}\right)$ is $<50 \%$ of the total POC. Both chlorophyll and POC vertical distributions illustrate the significant differences in autumn food availability between the surface layer and that below.

A clear relationship between krill and physical and biological patterns was observed on the vertical scale. The depth distribution of juvenile and immature adult Euphausia superba under ice (Fig. 6) was strongly correlated with the depth of the mixed layer and POC maxima, which ranged from 17.6 to $88.1 \mathrm{mg} \mathrm{C} \mathrm{m} \mathrm{m}^{-3}$. Although chlorophyll maxima usually were below the pycnocline, the highest chlorophyll concentrations $\left(0.07\right.$ to $\left.0.22 \mathrm{mg} \mathrm{m}^{-3}\right)$ were in the upper $100 \mathrm{~m}$, where all of the adults and more than $90 \%$ of the juveniles were collected during both day and night. Almost all (99\%) of the calyptopis larvae under the pack ice were in the upper $100 \mathrm{~m}$; however, most of the larvae (85\%) were concentrated between 50 and $100 \mathrm{~m}$, deeper than large krill. Also, the maximum larval concentration was deeper than the POC maximum but within the depth range of the chlorophyll maximum.

In open water, $97 \%$ of the juveniles and more than $90 \%$ of the adults occurred in the upper $100 \mathrm{~m}$ of the water column (Fig. 7), and the majority were above the pycnocline in higher POC (32.4 to $204.0 \mathrm{mg} \mathrm{m}^{-3}$ ) and chlorophyll concentrations ( 0.13 to $\left.1.79 \mathrm{mg} \mathrm{m}^{-3}\right)$. There was no evidence of diel changes (about $14 \mathrm{~h}$ of daylight) in vertical distribution of krill or differences in 


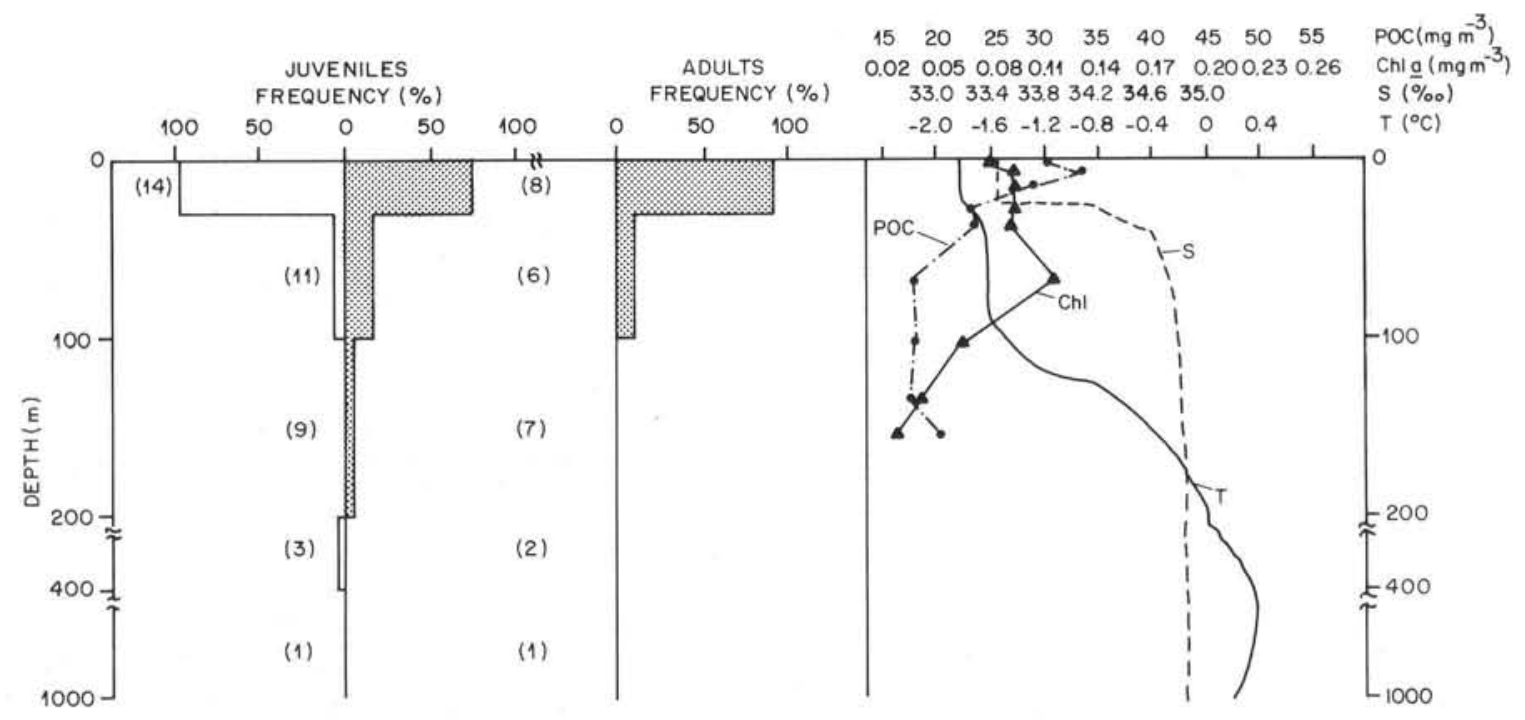

Fig. 6. Euphausia superba. Autumn vertical distributions of juvenile and adult krill under pack ice in relation to environmental variables. Frequency is percent abundance of krill during day (open steps) and night (shaded steps); number of net tows at each depth interval in parentheses. No adults were found in day tows. Vertical profiles include temperature (T), salinity (S), chlorophyll a (Chl), and particulate organic carbon (POC). Temperature and salinity profiles are from Stn 18. Chl and POC values at each depth are the mean of all stations where krill were collected. (Temperature and salinity data, R. Muench unpubl.; chl and POC data, W. Smith, Jr, unpubl.)

depth distribution between life history stage or sex; therefore, day/night tows were combined. The depth of maximum concentrations of larvae in open water is uncertain since plankton tows usually sampled large depth intervals (typically 0 to $250 \mathrm{~m}$ ) at stations where larvae occurred. However, calyptopis larvae were collected in 2 tows between 0 to 40 and 0 to $55 \mathrm{~m}$, indi- cating that some were near the surface. Metanauplius larvae, also present in open water, were collected in one 0 to $1200 \mathrm{~m}$ tow.

Winter. Leg 2 contour plots of temperature and salinity are shown in Fig. 8 in order to represent winter conditions, since too few transects were taken on Leg 1 to adequately resolve the distribution of these

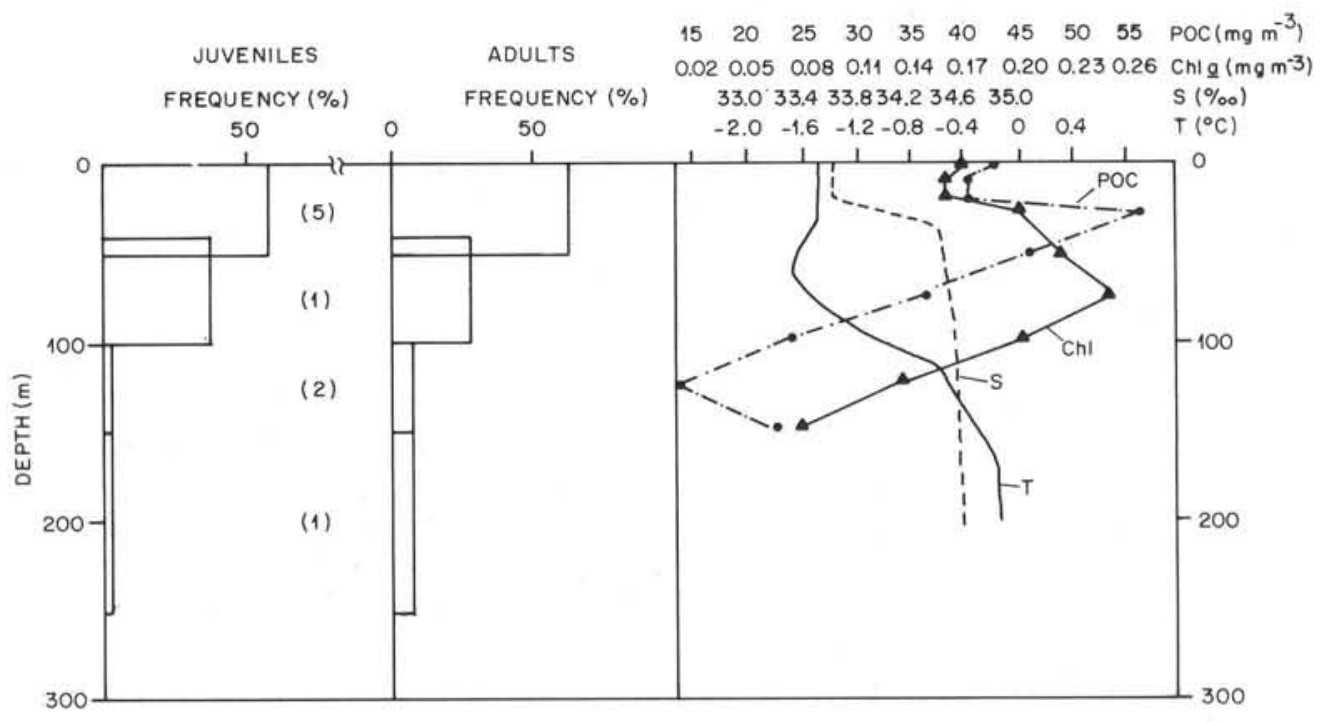

Fig. 7. Euphausia superba. Autumn vertical distributions of juvenile and adult krill in open water in relation to environmental variables. Frequency is percent abundance of krill (day/night data combined); number of tows at each depth interval in parentheses. Vertical profiles include temperature (T), salinity (S), chlorophyll a (Chl), and particulate organic carbon (POC). Temperature and salinity profiles are from Stn 10. Chl and POC values at each depth are the mean of all stations where krill were collected. (Temperature and salinity data, Husby \& Muench 1988; chl and POC data, W. Smith, Jr, unpubl.) 

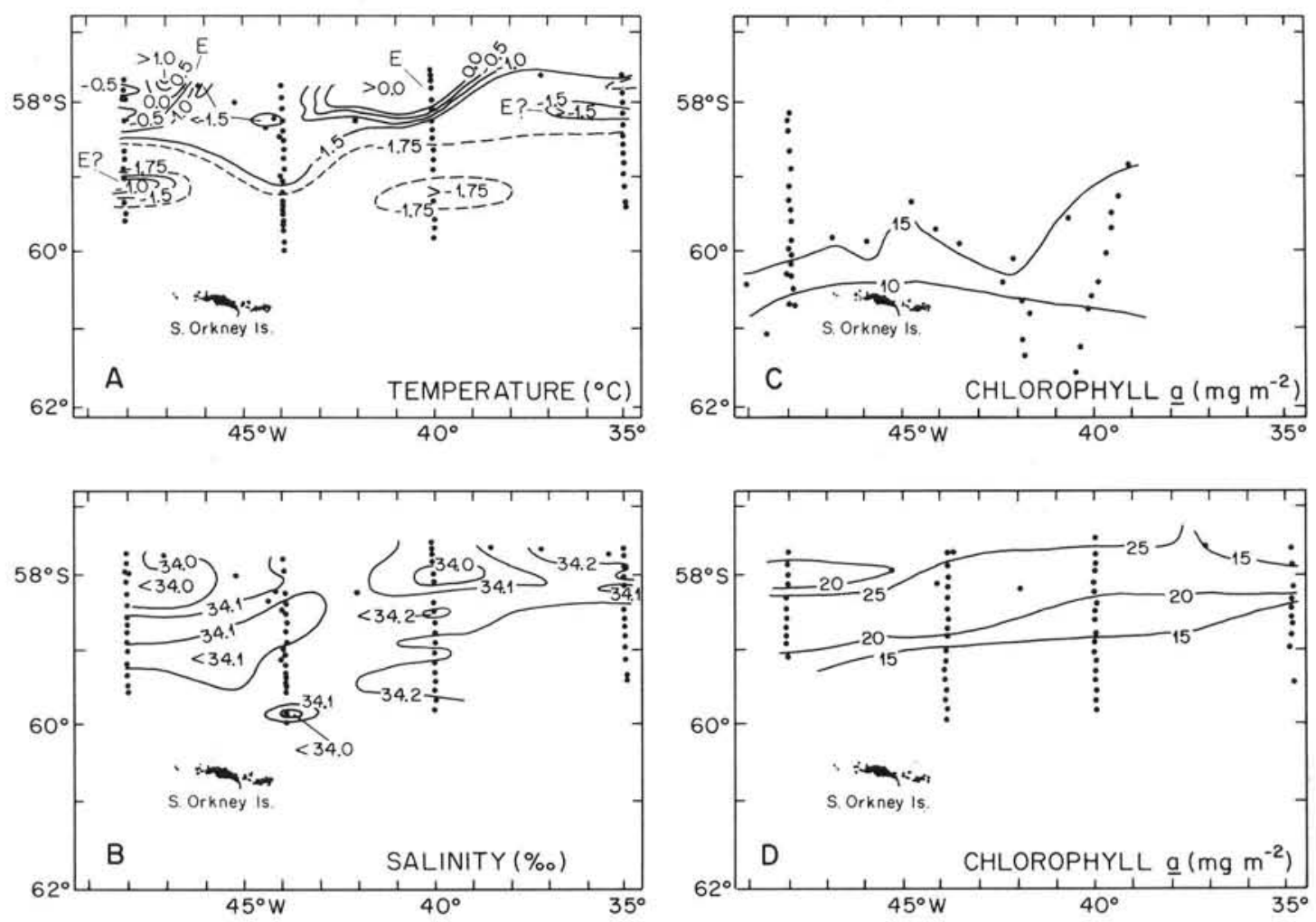

Fig. 8. Winter horizontal distribution of environmental variables: (A) temperature and (B) salinity at $50 \mathrm{~m}$ depth during Leg 2; (C) chlorophyll a integrated 0 to $150 \mathrm{~m}$ during Leg 1 and (D) during Leg 2. Dots represent locations of hydrographic stations. Warm cores of eddies (E) and eddy-like (E?) features are indicated in (A). Location of the ice edge during Legs 1 (9 June to 5 July 1988) and 2 (18 July to 14 August 1988) are shown in Fig. 9. [(A) and (B) from Muench et al. (1990); chlorophyll data from W. Smith, Jr (unpubl.)]

variables. Surface layer temperature (Fig. 8A) and salinity (Fig. 8B) fields reflect the presence of pack ice and complex circulatory features of this area. Temperatures were near freezing $\left(-1.8^{\circ} \mathrm{C}\right)$ under ice cover, increasing to $1.0^{\circ} \mathrm{C}$ at most northerly stations. Warmer Scotia Sea water and eddies originating in Polar Front water probably controlled the northern extent of sea ice (Husby et al. 1989). Salinity ( 34.0 to $34.2 \%$ ) showed only weak gradients. Integrated chlorophyll a was low ( 7 to $39 \mathrm{mg} \mathrm{m}^{-2}$ ) during this season (Fig. 8C, D). Phytoplankton biomass maxima often were assoçiated with the ice edge on Leg 1, yet there was no significant difference ( $t$-test, $\mathrm{p}=0.705$ ) between mean $( \pm 1 \mathrm{SD})$ integrated chlorophyll under the ice $\left(13.07 \pm 6.50 \mathrm{mg} \mathrm{m}^{-2}\right.$, $\mathrm{n}=27)$ and in open water $\left(13.75 \pm 3.62 \mathrm{mg} \mathrm{m}^{-2}, \mathrm{n}=16\right)$. Although still very low, phytoplankton biomass increased in open water between the 2 phases of the field program. On Leg 2, mean integrated chlorophyll in open water $\left(19.91 \pm 4.42 \mathrm{mg} \mathrm{m}^{-2}, \mathrm{n}=35\right.$ ) was significantly higher $(t$-test, $\mathrm{p}<0.001)$ than that under the ice (14.59 $\left.\pm 4.40 \mathrm{mg} \mathrm{m}^{-2}, \mathrm{n}=27\right)$.

Age- 0 furciliae and juveniles, juveniles (age-1+), and immature adult Euphausia superba were widely distributed over the study area (Fig. 9). During winter the location of the ice edge varied considerably within days. Reoccupied open-water stations became icecovered or vice versa, making it difficult to depict in figures the spatial distribution of krill in relation to the ice edge. However, frequency of occurrence at stations in open water, at the ice edge $(0$ to $2 \mathrm{~km}$ into the pack ice), and under pack ice ( $>2 \mathrm{~km}$ into the ice) suggests that larvae were more ubiquitous than older stages (Table 4). Juveniles were collected more frequently in open water, while adults were usually collected under the ice. Combining the results of both cruises, the median density of larvae collected from the ice edge was significantly higher (median test, $p<0.001$ ) than at open-water or deeper pack-ice stations (Table 5). Juvenile and adult densities were not significantly different (median test, $\mathrm{p}=0.05$ ) between locations; however, the median density of all life history stages was an order of magnitude higher at ice-edge stations than elsewhere.

Female and male krill occurred together at most stations (Fig. 9). Females were dominant at $63 \%$ of the stations. Where both sexes occurred, females were 25 to $89 \%$ of the adults and males were 11 to $66 \%$. There were no apparent differences in distri- 
Leg 1
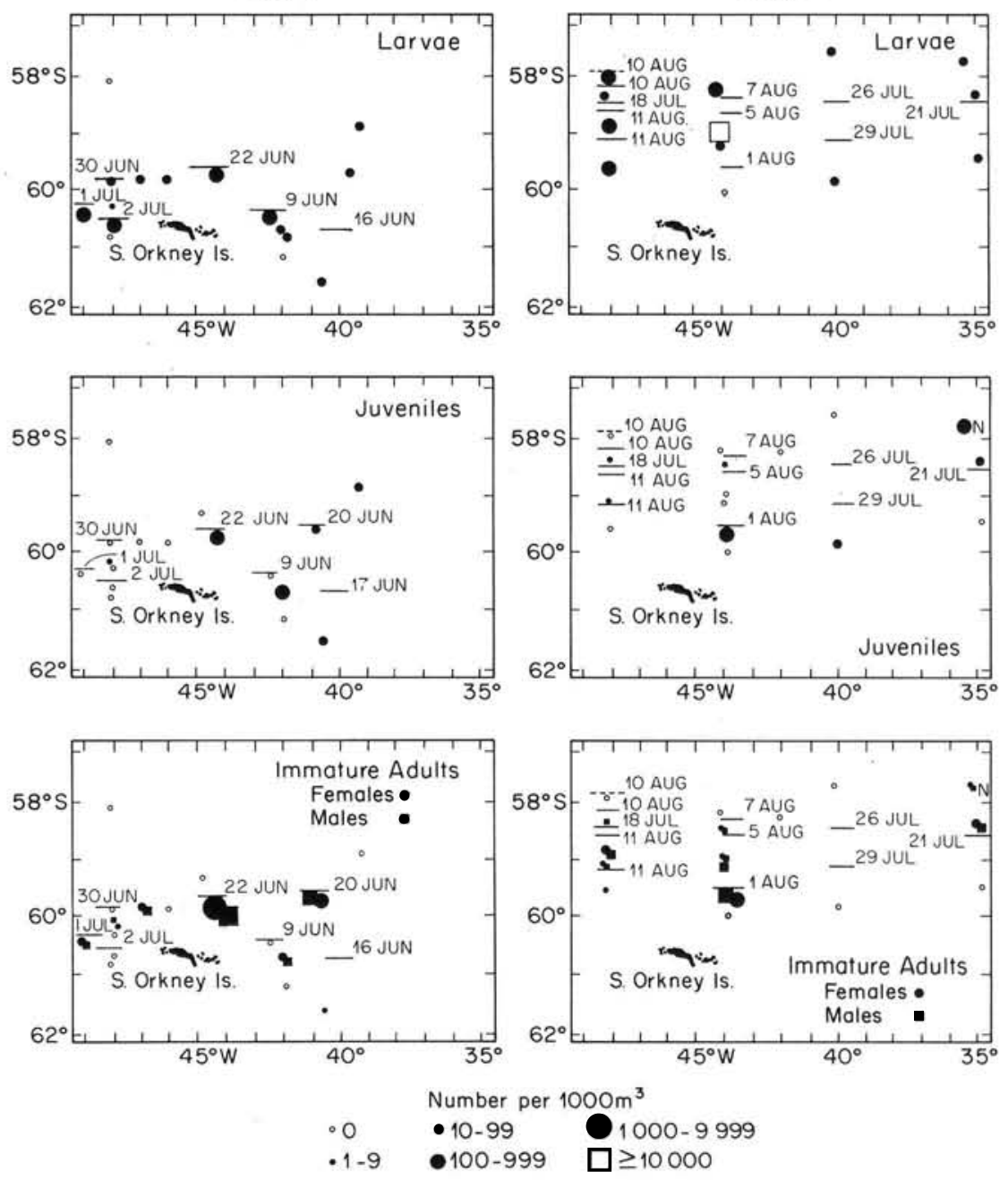

Leg 2
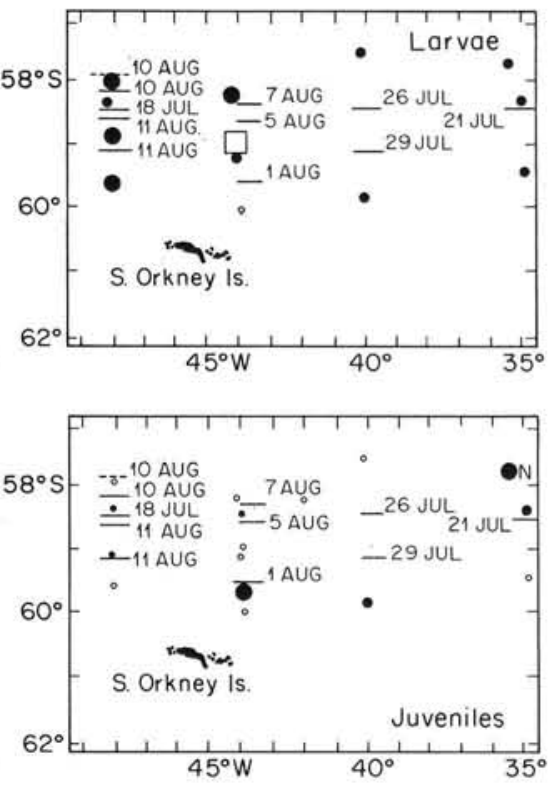

Fig. 9. Euphausia superba. Winter horizontal distribution of life history stages of krill during Legs 1 and 2. Abundance (no. per $1000 \mathrm{~m}^{3}$ ) indicated by symbol size. Larvae include age- 0 furciliae and juveniles. Approximate position of ice edge denoted by horizontal lines and dates. The location of stations with respect to a receding or advancing ice edge is inferred from the progression of dates (e.g. Leg $2,45^{\circ} \mathrm{W}$ transect, ship sampled northward with an advancing ice edge). $\mathrm{N}$ : location of non-quantitative collection of krill from the engine intake filter at $5 \mathrm{~m}$ depth bution of females and males between open-water and under-ice stations.

In this study, the winter site was the only one that had stations over a shelf slope (Stns 1 to 7 and 31 to 41 ; Fig. 1B). No discernable difference in densities of krill was noted between the shelf slope stations and those in deep water. Also, several eddies were identified in winter (Fig. 8A), 2 with surface speeds of 30 to $>40 \mathrm{~cm} \mathrm{~s}^{-1}$ (Muench et al. 1990). Unfortunately, few stations were sampled within the eddies and no difference in densities was observed in these areas compared to stations outside of eddies.

Young Euphausia superba were frequently sighted just below the water surface along the edges of ice floes throughout the study area but the distribution and abundance of krill on the undersurfaces of ice floes during winter is unknown because divers were not available. However, visual estimates of larvae on the sides of ice floes were as high as 1000 ind. $\mathrm{m}^{-2}$. Krill collected from ice floes on Leg 1 were furcilia (F3 to 6),

Table 4. Percent and number (n) of stations where various life history stages of Euphausia superba were collected in ice-covered, ice-edge, and open water during Legs 1 and 2 of the winter survey

\begin{tabular}{|c|c|c|c|c|c|c|}
\hline \multirow[t]{2}{*}{ Stage } & \multicolumn{3}{|c|}{ Leg 1} & \multicolumn{3}{|c|}{ Leg 2} \\
\hline & $\begin{array}{l}\text { Ice-covered } \\
(2-200 \mathrm{~km})\end{array}$ & $\begin{array}{l}\text { Ice-edge } \\
(0-2 \mathrm{~km})\end{array}$ & Open & $\begin{array}{l}\text { Ice-covered } \\
(2-200 \mathrm{~km})\end{array}$ & $\begin{array}{l}\text { Ice-edge } \\
(0-2 \mathrm{~km})\end{array}$ & Open \\
\hline Larvae & $75(8)$ & $100(5)$ & 67 (3) & $75(4)$ & $100(5)$ & $100(4)$ \\
\hline Juveniles & $29(7)$ & $25(8)$ & $50(4)$ & $29(7)$ & $67(3)$ & $71(7)$ \\
\hline Adults & $29(7)$ & $50(8)$ & $25(4)$ & $57(7)$ & $67(3)$ & $57(7)$ \\
\hline
\end{tabular}


Table 5. Euphausia superba. Winter median density (no. per $1000 \mathrm{~m}^{3}$ ) and range of krill life history stages in ice-covered, ice-edge, and open water

\begin{tabular}{|lccc|}
\hline Stage & $\begin{array}{r}\text { Ice-covered } \\
(2-200 \mathrm{~km})\end{array}$ & $\begin{array}{c}\text { Ice-edge } \\
(0-2 \mathrm{~km})\end{array}$ & Open \\
\hline Larvae & 30 & 170 & 15 \\
Juveniles & 96 & 152 & $(10-70)$ \\
& $(10-310)$ & $(50-63480)$ & 30 \\
Adults & 27 & 205 & $(0.2-1252)$ \\
& $(10-1031)$ & $(3-3240)$ & $(1-2392)$ \\
\hline
\end{tabular}

5 to $12 \mathrm{~mm}$ in length (Fig. 10). A similar size distribution was collected in the water column under the ice and in open water. Sizes of juveniles (age-1+) and immature adults under ice also overlapped considerably with those in open water on both legs. Even though there appeared to be little difference in size distribution between habitats in this season, all life history stages were more abundant under the ice.

Vertical distributions of juveniles and adults were similar between day and night, between open-water and under-ice conditions, and between sexes, and because few individuals were collected in open water, these data were combined. Almost the entire population of juvenile and immature adult krill occurred above the pycnocline in the same depth range as the highest chlorophyll and POC concentrations (Fig. 11). Although maximum chlorophyll concentrations $(0.06$ to $0.32 \mathrm{mg} \mathrm{m}^{-3}$ ) were lower than maxima observed in other seasons, maximum POC concentrations (43.7 to $586.0 \mathrm{mg} \mathrm{m}^{-3}$ ) were slightly higher than in autumn. Larval krill sampled under pack ice, at the ice edge, and in open water showed a vertical distribution similar to that of older krill (Fig. 12). Winter photoperiods were short (ca $6 \mathrm{~h}$ of daylight in June, increasing to $8 \mathrm{~h}$ in August) and no diel vertical migration was evident for any life history stage.

Spring. Surface temperatures showed a strong gradient with distance from the ice edge, increasing from $-1.8^{\circ} \mathrm{C}$ to $0.5^{\circ} \mathrm{C}$ as during previous seasons (Fig. 13A). Salinity was highest under the pack ice $(33.4 \%)$ and decreased towards the ice edge, with minima $(34.0 \%)$ in meltwater regions near the ice edge and at the northern edge of the marginal ice zone (Fig. 13B). Integrated chlorophyll a was low under the ice and 5 to 100 times greater in open water (Fig. 13C),
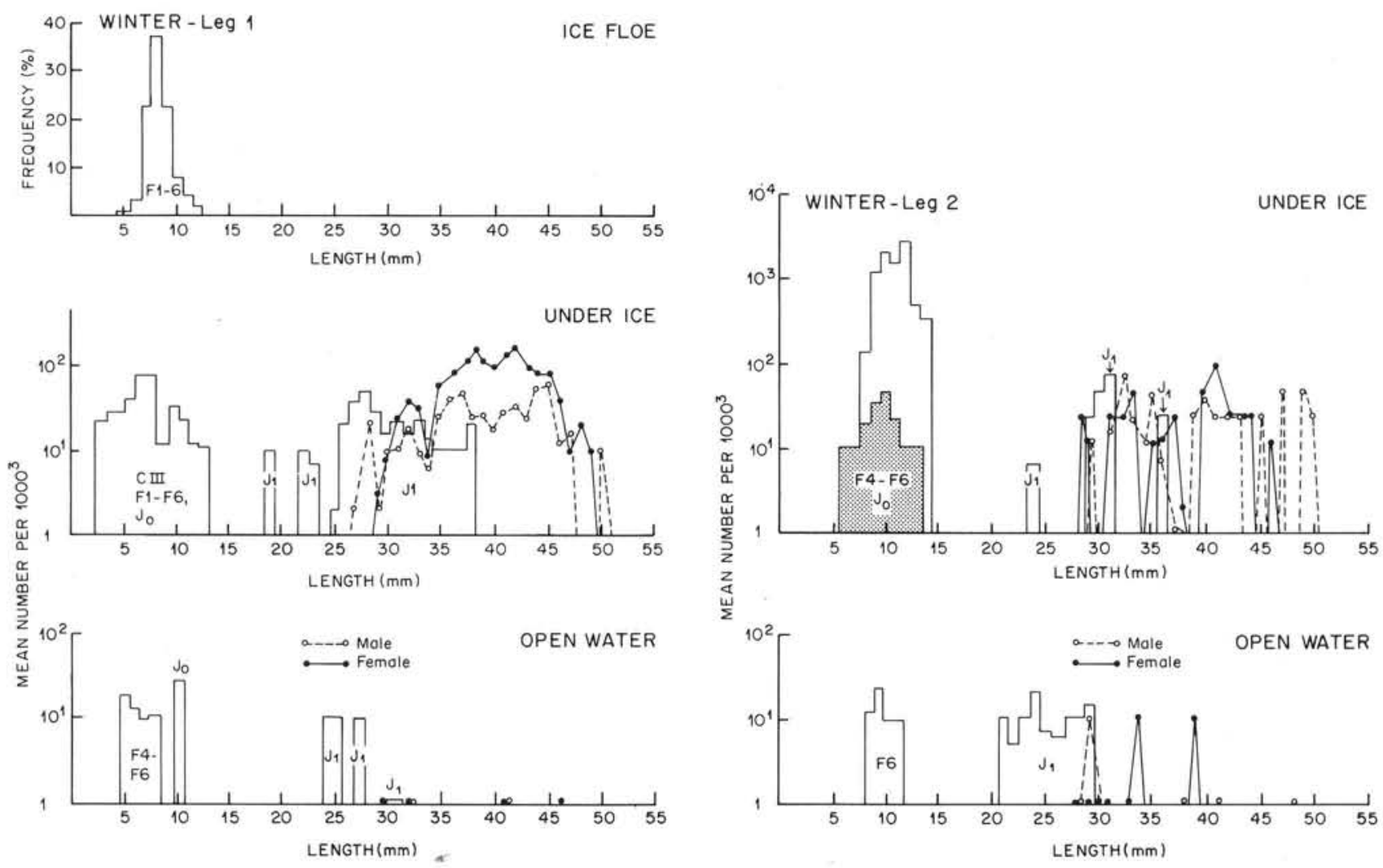

Fig. 10. Euphausia superba. Winter length-frequency distributions of krill in relation to ice: undersurface of ice floes (Leg 1), in water column under pack ice and in open water (Legs 1 and 2). For Leg 2 under ice, shaded area is larval swarm from Stn 119 ; unshaded area is from all net samples. C: calyptopis; $F$ : furciliae; $\mathrm{J}_{0}$ : age-0 juveniles; $\mathrm{J}_{1}$ : age- $1+$ juveniles; males and females are immature adults 


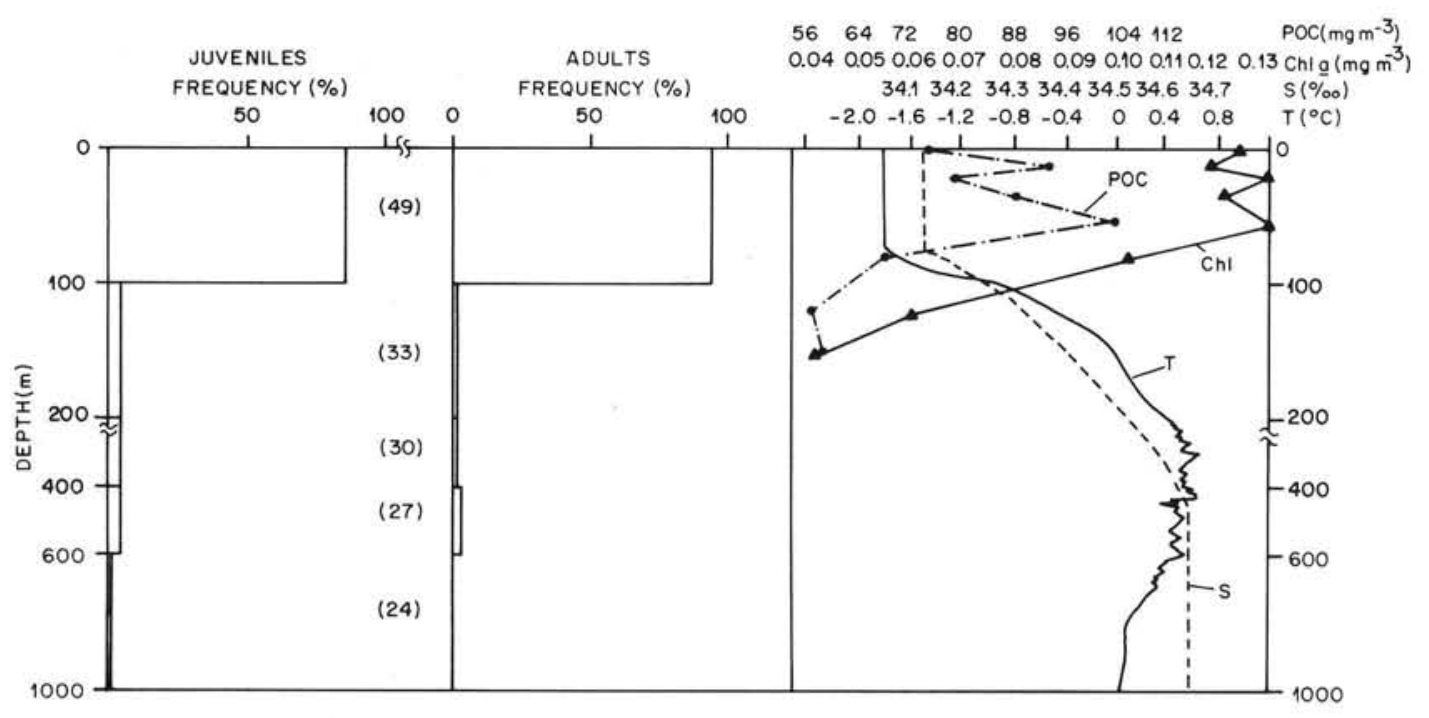

Fig. 11. Euphausia superba. Winter vertical distributions of juvenile and adult krill in relation to environmental variables. Frequency is percent abundance of krill (day/night and under ice/open water data combined); number of net tows at each depth interval in parentheses. Vertical profiles include temperature (T), salinity (S), chlorophyll a (Chl), and particulate organic carbon (POC). Temperature and salinity profiles are from Stn 113, Chl and POC values at each depth are the mean of all stations where krill were collected. (Temperature and salinity profiles, Muench et al. 1990; chl and POC data, W. Smith, Jr, unpubl.)

with pronounced maxima at ca $59^{\circ} \mathrm{S}$ near the Scotia Sea front and in a large bloom at the western side of the ice edge in the Weddell-Scotia Confluence.

First-year (age-0) juvenile krill were collected under the ice and in open water although maximum concentrations were on the eastern transect under the ice and in the vicinity of the phytoplankton bloom in open water (Fig. 14). The larger individuals in open water may have been age- 1 juveniles. Immature and mature adults also were concentrated in the large bloom in open water but none were collected by nets under the ice. All life history stages of krill, however, were found in guts of seabirds and seals collected in the ice, and immature and mature males were dominant (K. Daly unpubl.), suggesting that adults did occur under the ice. The numerous small swarms acoustically detected under the ice may have consisted primarily of adults. Unfortunately, attempts to sample these swarms with the vertical plummet net were unsuccessful. Densities of all stages in open water were low compared to those of other seasons, while under-ice densities of juveniles were similar to larval and juvenile densities in preceding seasons (Table 6). Furthermore, juvenile densities in spring were significantly higher (median test, $\mathrm{p}=0.003$ ) under ice than in open water.

Females and males did not occur together at $53 \%$ of the open water stations (Fig. 14), which may have been an artifact of sampling adults at low densities. Sex ratios of immature adults were $1: 1$ in 2 samples; immature females were dominant in 3 samples (59 to $75 \%)$ and immature males in 1 sample $(87 \%)$. Of the sexually maturing females, $73 \%$ were carrying spermatophores but none were gravid. Mature
Fig. 12. Euphausia superba. Winter vertical distributions of larval krill under solid pack ice, at the ice edge, and in open water. Frequency is percent abundance of larvae (day/night data combined); number of net tows at each depth interval in parentheses. Schematic representations of the pack-ice, ice-edge, and open-water habitats are above the respective vertical profiles

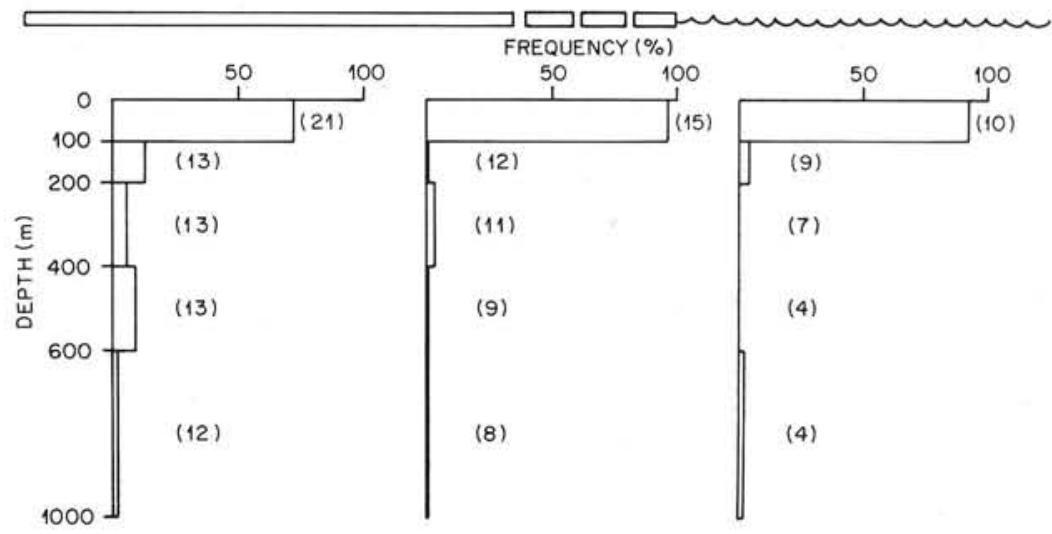



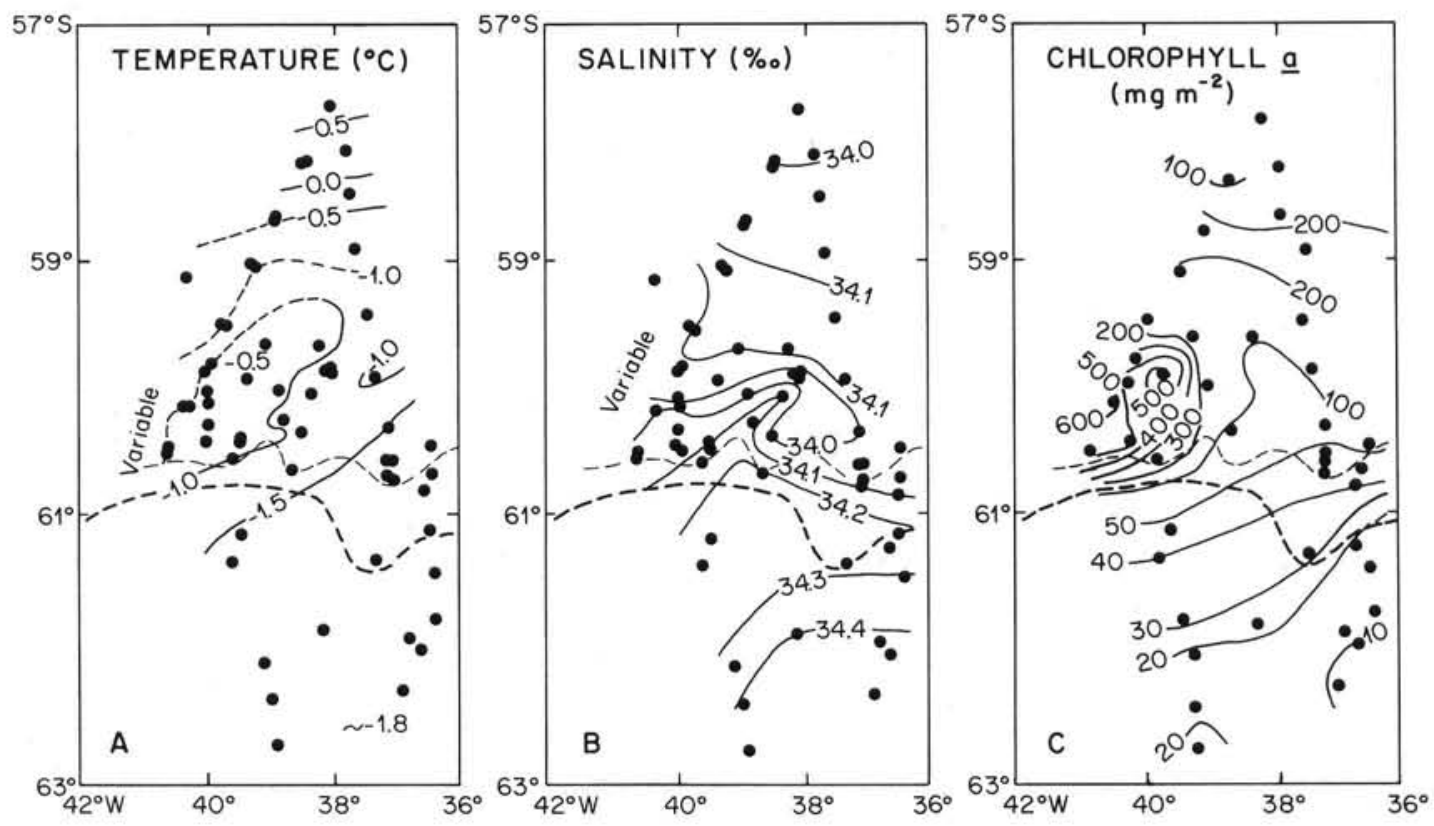

Fig. 13. Spring horizontal distribution of environmental variables: (A) temperature and (B) salinity at $10 \mathrm{~m}$ depth, and (C) chlorophyll $a$ integrated 0 to $100 \mathrm{~m}$. Dots represent locations of hydrographic stations. The upper dashed line is the outer limit of bands of ice; the lower dashed line denotes the approximate location of the ice edge. [(A) and (B), R. Muench \& B. Huber (unpubl.); chlorophyll data from Nelson et al. (1987) and W. Smith, Jr (unpubl.)]
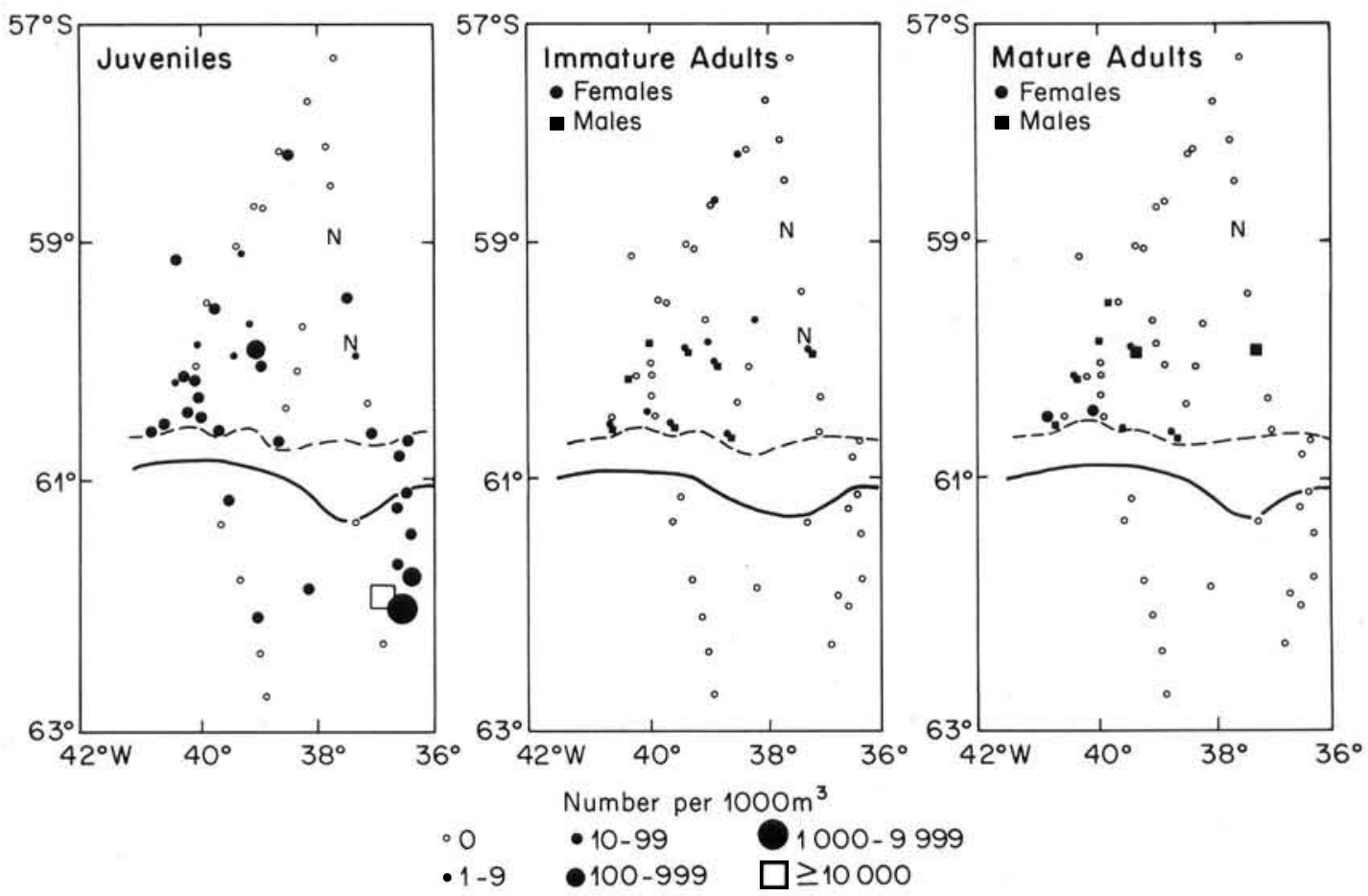

Fig. 14. Euphausia superba. Spring horizontal distribution of life history stages of krill. Abundance (no. per $\left.1000 \mathrm{~m}^{3}\right)$ indicated by symbol size. Juveniles include age- 0 and possibly age- 1 individuals. The continuous line denotes the approximate location of the ice edge; bands of ice occurred between the dashed line and the ice edge. $\mathrm{N}$ : locations of non-quantitative surface Bongo tows. 
Table 6. Euphausia superba. Spring median density (no. per $1000 \mathrm{~m}^{3}$ ) and range of krill life history stages in ice-covered and open water

\begin{tabular}{|lcc|}
\hline Stage & Ice-covered & Open \\
\hline Juveniles & 40 & 16 \\
& $(10-76800)$ & $(2-161)$ \\
Immature adults & - & 4 \\
& & $(1-10)$ \\
Mature adults & - & 9.5 \\
& & $(1-29)$ \\
\hline
\end{tabular}

females also were dominant in three samples (55 to $75 \%$ ) and males were dominant in 1 sample (80\%).

During spring, juvenile Euphausia superba were observed on numerous occasions on the undersurface of ice floes overturned by the ice breaker and divers saw small krill feeding inside brine channels in decaying ice floes. These krill were juveniles (11 to $19 \mathrm{~mm}$ long; Fig. 15). In the water column under the ice, only small late-stage furciliae and juveniles (9 to $24 \mathrm{~mm}$ long) were collected, whereas larger juveniles were collected in open water. The length of adults found in guts of pack ice seabirds (Ainley et al. 1988)
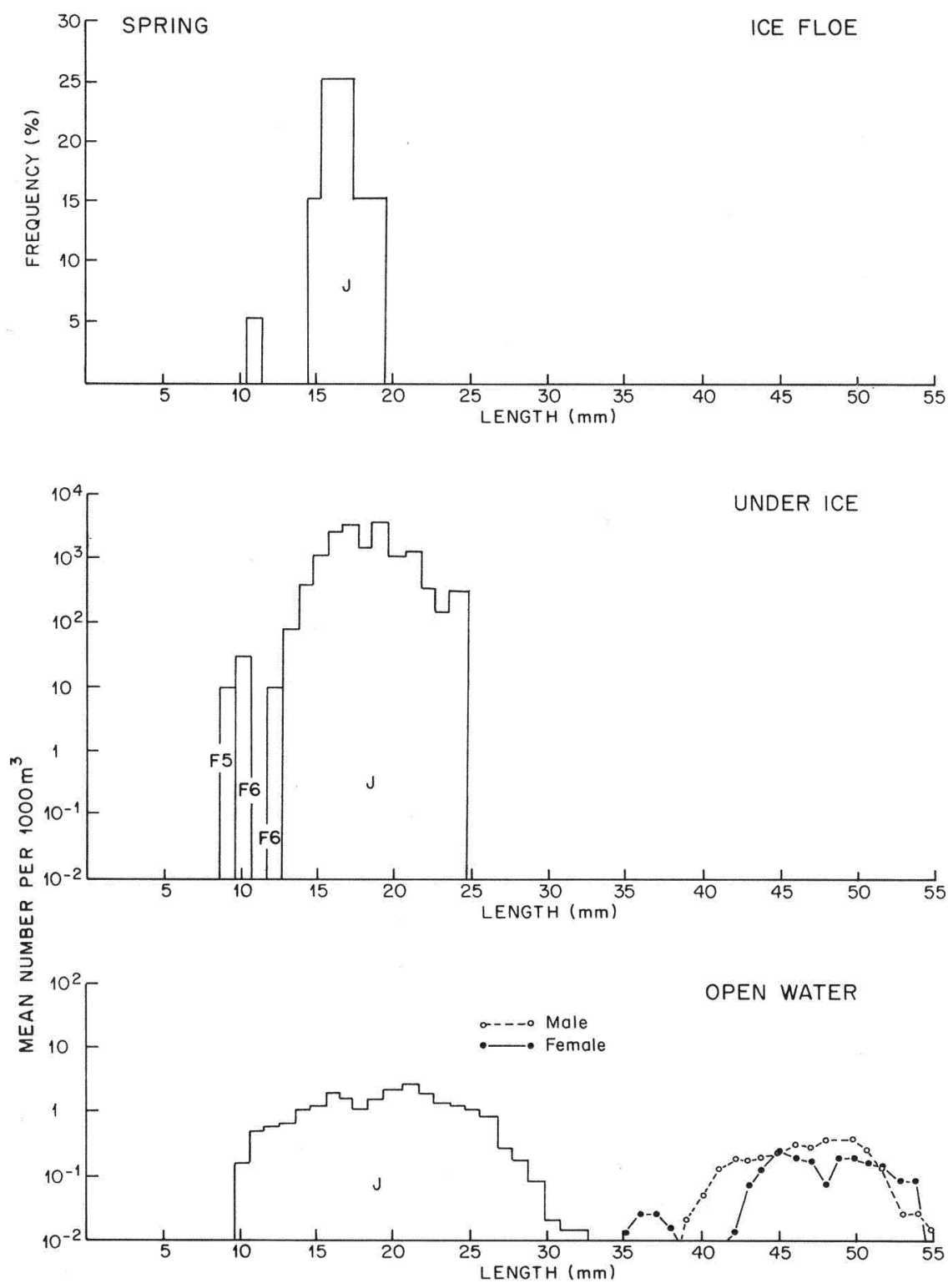

Fig. 15. Euphausia superba. Spring length-frequency distributions of krill in relation to ice: undersurface of ice floes, water column under pack ice, and in open water. F: furciliae; J: juveniles, age-0 and possibly age-1; males and females include immature and mature adults. (Open-water data from E. Brinton unpubl.) 


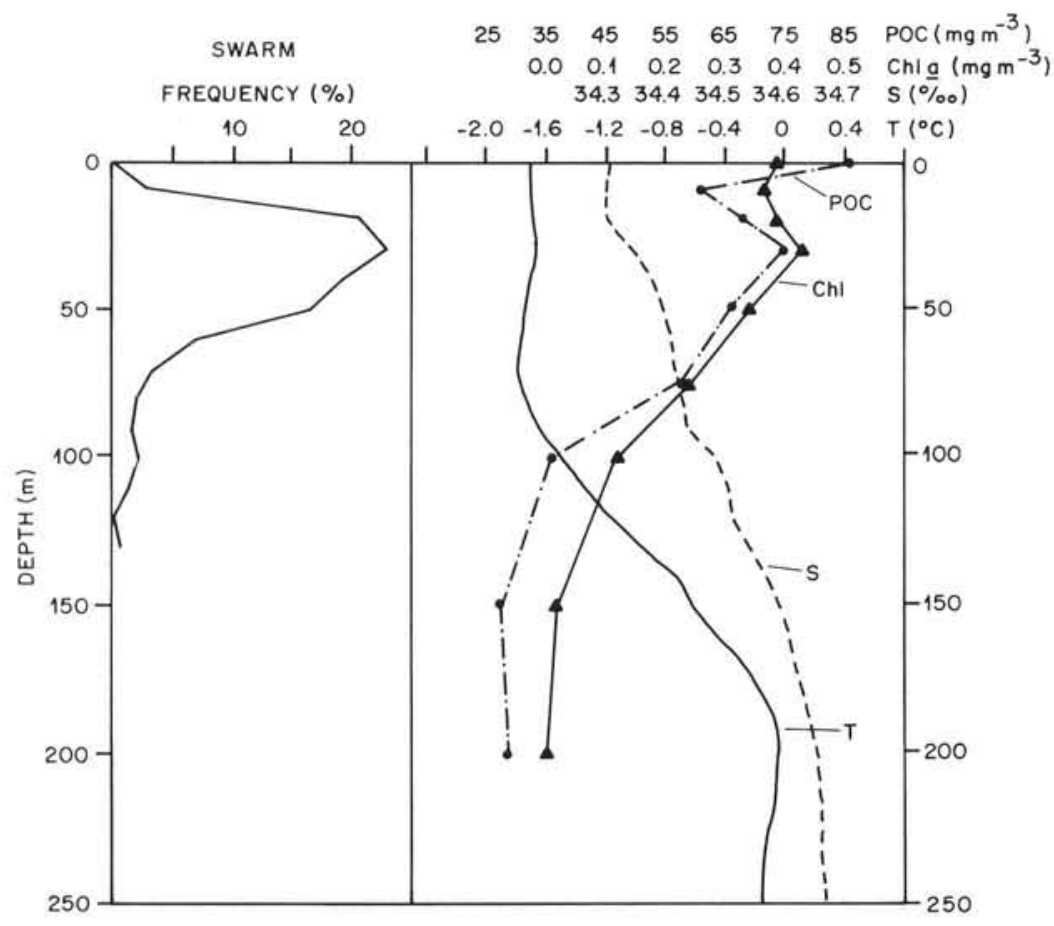

Fig. 16. Euphausia superba. Spring vertical distribution of acoustically detected swarms under pack ice in relation to environmental variables. Frequency is percent abundance of swarms (day/night data combined). Vertical profiles include temperature $(\mathrm{T})$, salinity $(\mathrm{S})$, chlorophyll a $(\mathrm{Chl}$ a), and particulate organic carbon (POC). Temperature and salinity profiles are from Stn 16. Chl and POC values at each depth are the mean of Stns 15 to 19. (Temperature and salinity data, Nelson et al. 1987; chl and POC data, W. Smith, Jr, unpubl.)

and a seal (Daly \& Macaulay 1988) were similar in size (33 to $56 \mathrm{~mm}$ ) to those in open water.

Depths of acoustically detected swarms were used to infer the vertical distribution of krill under ice because net tows were not taken at discrete depth intervals. There was no significant difference in the mean depth or frequency of swarms between day and night (Daly \& Macaulay 1988); therefore, these data were combined. Most swarms occurred in the upper $50 \mathrm{~m}$ of the water column in the region of vertical stability and highest food availability (Fig. 16). Open-water depth distributions of krill could not be determined from Bongo net tows that sampled 0 to $200 \mathrm{~m}$; however, Tucker trawl collections indicate krill in open water also occurred primarily in the upper $100 \mathrm{~m}$ of the water column (Lancraft et al. 1989). Maximum chlorophyll concentrations ( 0.10 to $0.68 \mathrm{mg} \mathrm{m}^{-3}$ ) were low under the ice and increased to 0.32 to $12.87 \mathrm{mg} \mathrm{m}^{-3}$ in open water. Maximum POC concentrations were similar under the ice ( 44.1 to $262.4 \mathrm{mg} \mathrm{m}^{-3}$ ) and in open water (32.3 to $387.7 \mathrm{mg} \mathrm{m}^{-3}$ ). No diel changes (ca $18 \mathrm{~h}$ light) in depth distribution of krill not in swarms were evident from acoustic results (Daly \& Macaulay 1988).

\section{Swarming behavior}

Autumn. Euphausia superba were widely dispersed at low densities throughout the study area. One swarm sampled by plummet net under the ice (Stn 28) was composed of immature adults (99\%) and a few juveniles. No layers or other swarms were detected by acoustic or net methods under the ice and none were detected acoustically in open water. Aggregating behavior of juveniles on the undersurface of ice floes in concentrations of sea ice biota was in contrast to dispersed behavior in the water column.

Winter. Krill generally were dispersed throughout the study area; however, a number of swarms were observed, particularly near the ice edge. What may have been a surface swarm was sighted near Stn 28 about midday in a large lead. A group of 65 minke

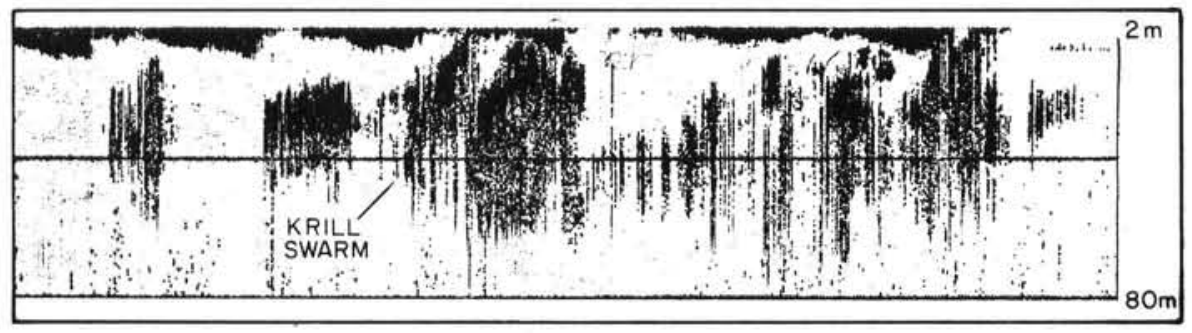

Fig. 17. Euphausia superba. Winter acoustic echogram of swarms of krill under pack ice at Stn $33 ; 11: 00$ h local time; time scale $=$ ca $15 \mathrm{~min}$; depth scale $=$ surface to $80 \mathrm{~m}$. Swarm composition unknown 
whales Balaenoptera acutorostrata and many seabirds appeared to be feeding at the surface in reddish water. In addition, numerous swarms extending from near surface to about 40 or $60 \mathrm{~m}$ in depth were acoustically detected about midday at Stn 33 (Fig. 17), where nearby thousands of penguins and some seals were observed. A number of small, near-surface $(0$ to $20 \mathrm{~m})$ swarms also were detected after dark at Stns 114 and 119 .

Plummet nets and Tucker trawls sampled swarms at a number of stations. Plummet nets collected concentrations of furcilia larvae (F4 to 6 ) and age- 0 juveniles at Stns 27, 36, 119, and 142. The length frequency of larvae from the swarm at Stn 119 is shown in Fig. 10. Due to large net sampling intervals ( 0 to $100 \mathrm{~m}$ ), the exact depth of larval swarms could not be determined, but echograms suggest they were between 0 and $20 \mathrm{~m}$. Larvae also were observed to aggregate on the sides of ice floes. Tucker trawls collected concentrations of juvenile and immature adults at Stns 22 and 114 between 0 and $40 \mathrm{~m}$ depth. These swarms were primarily immature adults ( 89 and $86 \%$, respectively) and some juveniles.

Swarms were not observed in open water, yet hundreds of live Euphausia superba were found in the ship's engine intake filter near Stn 70 and between Stns 71 and 72, suggesting that krill occasionally were concentrated near surface in open water. Those krill were predominately juveniles ( 84 and $95 \%$ ), 20 to $35 \mathrm{~mm}$ in length, but included some immature females and males, 27 to $46 \mathrm{~mm}$ in length.

Spring. More complex behavior was observed in spring, both in open water and under the ice. Throughout the study area, krill typically were very dispersed, but they also formed layers and small swarms. Under the ice, acoustic sampling detected a layer about $25 \mathrm{~m}$ deep at Stn 2 and swarms at $71 \%$ of the other stations. The mean ( $\pm 1 \mathrm{SD}$ ) frequency of swarms (no. swarms ${ }^{-1}$ ) at each station was significantly higher ( $t$-test, $\mathrm{p}=0.003)$ on the western transect $(8.0 \pm 4.7, \mathrm{n}=6)$ than on the eastern transect $(2.9 \pm 1.7, \mathrm{n}=12)$. With one exception, all attempts to sample these swarms were unsuccessful due to ice conditions restricting net sampling to vertical tows that were avoided by krill swarms. From acoustic echograms, the one swarm sampled by plummet net appeared to be descending from the undersurface of an ice floe (Fig. 18) and was composed entirely of juveniles, 13 to $24 \mathrm{~mm}$ in length. Most of the other swarms were smaller and deeper in the water column (Fig. 19) and may have been composed of adults, especially those on the western transect as indicated from gut contents of predators.

Since food availability and predation may affect swarming behavior, the frequency of swarms along the western transect was examined in relation to integrated chlorophyll and POC, and to density of predators (Fig. 20). Food supply was lowest under the ice but increased towards the ice edge and was highest in open water. In contrast, density of seals and seabirds was highest from $150 \mathrm{~km}$ into the pack ice to the ice edge, the area with the highest frequency of swarms. The implications of this relationship are important. These results suggest that predation rather than food availability may have influenced the higher occurrence of swarms in this area.

No swarms were sampled by nets in open water. However, 2 non-quantitative surface tows collected predominately juvenile krill. The first sample $(n=268)$ contained $72 \%$ juveniles (16 to $25 \mathrm{~mm}$ ), $18 \%$ immature adults ( 26 to $44 \mathrm{~mm}$ ) and $10 \%$ mature adults $(45$ to $50 \mathrm{~mm})$ and the second sample $(\mathrm{n}=568)$ contained $98 \%$ juveniles ( 12 to $25 \mathrm{~mm}$ ) and $2 \%$ immature females ( 26 to $27 \mathrm{~mm}$ ).
Fig. 18. Euphausia superba. Spring acoustic echogram of a single large swarm of juvenile krill under pack ice at Stn 5; 19:15 h local time; time scale $=$ ca $13 \mathrm{~min}$; depth scale $=$ surface to $50 \mathrm{~m}$. Swarm composition determined from plummet net samples. (Modified from Daly \& Macaulay 1988)

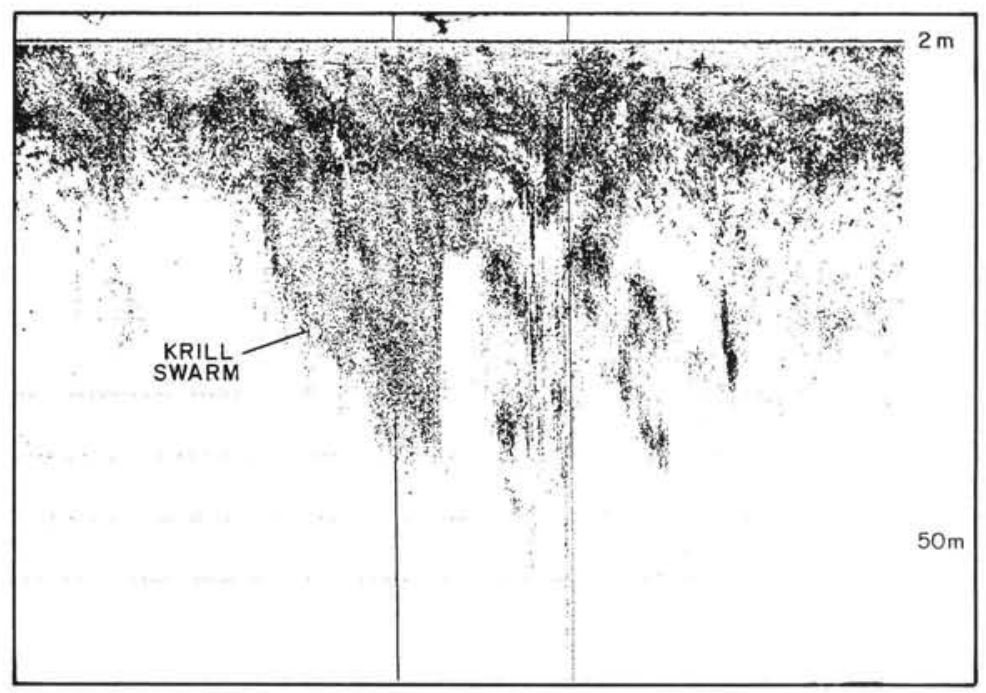




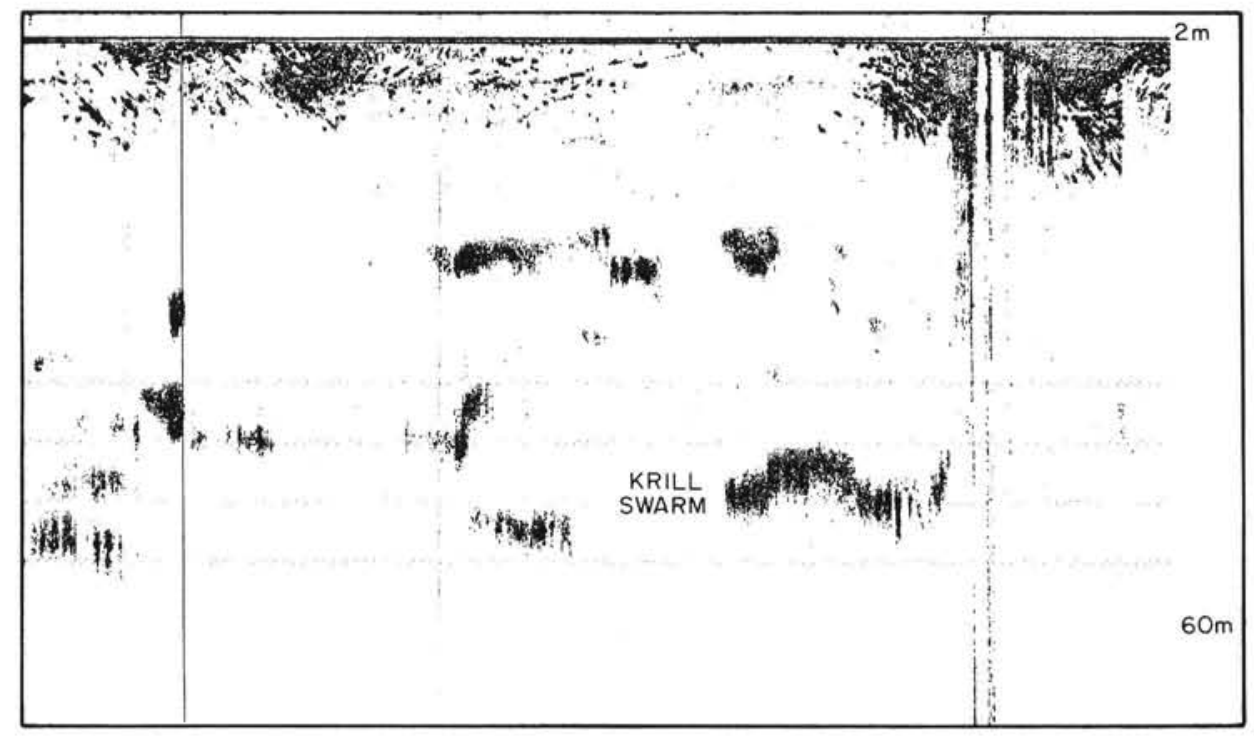

Fig. 19. Euphausia superba. Spring acoustic echogram of typical small, discrete swarms of krill under pack ice at Stn 16; 07:09 h local time; time scale $=$ ca $15 \mathrm{~min}$; depth scale $=$ surface to $80 \mathrm{~m}$. Swarm composition unknown. (Modified from Daly \& Macaulay 1988)

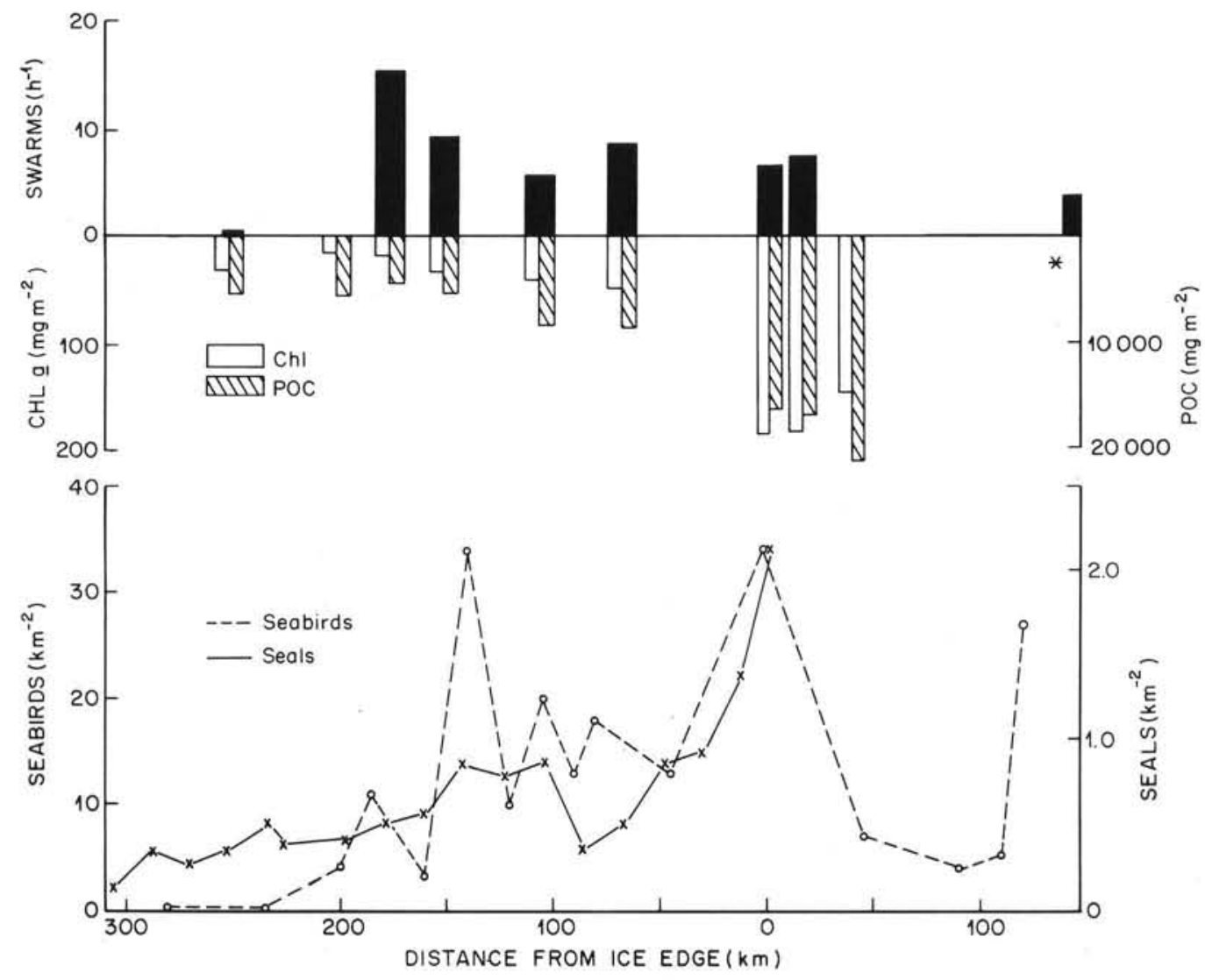

Fig. 20. Euphausia superba. Spring horizontal distribution of swarms in relation to distance from the ice edge, food availability, and predator density. Chlorophyll a (Chl a) and particulate organic carbon (POC) are integrated to $100 \mathrm{~m}$ (*: chl and POC concentrations unknown), and densities of swarms (see Fig. 19 for examples), seals and seabirds are from the western transect, Stns 14 to 23 (see Fig. 1C); open water is shown to the right of the ice edge $(0 \mathrm{~km})$. (Seal data, Erickson 1984; seabird data, Fraser \& Ainley 1986; chl and POC data, W. Smith, Jr, unpubl.) 


\section{DISCUSSION}

\section{Mesoscale dynamics in the marginal ice zone}

Physical processes. The spatial relationships of ice cover, seawater temperature and salinity, and chlorophyll $a$ during this study were influenced by physical processes associated with marginal ice zones and large-scale circulation patterns at each study site. During the 3 seasons, ice cover and meltwater affected seawater temperatures. In the upper mixed layer, temperature showed a strong gradient relative to the ice margin, ranging from $-1.8^{\circ} \mathrm{C}$ under the pack ice to ca $0^{\circ} \mathrm{C}$ seaward of the ice edge. However, meridional changes in temperature along the ice edge reflected mesoscale circulation patterns in winter and spring. The southeastern Scotia Sea region (winter and spring study sites) was characterized by energetic currents ( 5 to $50 \mathrm{~cm} \mathrm{~s}^{-1)}$ and mesoscale features, such as eddies and complex mixing of water masses from the Drake Passage and the Weddell Sea, while the Weddell Sea (autumn study site) had no such mesoscale activity and currents were barely detectable (Muench et al. 1992).

Enhanced stratification normal to the ice edge due to a low-salinity meltwater lens was present during all seasons. In autumn, low salinities (33.1 to $33.8 \%$ ) and a shallow surface mixed layer above a strong pycnocline at 30 to $50 \mathrm{~m}$ were the result of continuous ice melt during the previous summer (Muench et al. 1992). Because the ice edge was essentially stationary in autumn, the lowest salinities occurred adjacent to the ice edge. Salinities were higher ( 34.0 to $34.4 \%$ ) at the winter and spring study sites. Even though active ice melting occurred in these seasons also, the low salinity meltwater was rapidly advected away from the ice edge (Muench et al. 1992). Stratification also was weaker during winter and spring, with mixed layer depths varying between 80 and $140 \mathrm{~m}$ and between 30 and $140 \mathrm{~m}$, respectively. The lowest salinities in these 2 seasons did not occur immediately adjacent to the ice margin but in several locations within $35 \mathrm{~km}$ of the ice edge, perhaps as a result of episodic melting (by eddies in winter) and, in spring, a rapidly retreating ice edge.

Food availability. Based on summer studies, Euphausia superba are considered to be herbivores (Miller \& Hampton 1989); therefore, the distribution of chlorophyll $a$, as an estimate of phytoplankton (autotrophic) biomass, generally has been used to infer food availability for krill (e.g. Holm-Hansen \& Huntley 1984). However, gut contents of individuals from all life history stages examined in autumn and winter contained heterotrophic organisms and detritus in addition to phytoplankton (Hopkins \& Torres 1989, Daly 1990, Lancraft et al. 1991). Although the amount of nutrition derived from non-phytoplankton food is unknown, particulate organic carbon (POC), which includes all potential sources of food, living (autotrophic and heterotrophic) and nonliving (detrital), probably is a better indicator of food resources in these seasons.

Physical processes strongly influenced the distribution and abundance of food. Vertical stratification of the water column induced by melting ice was important in the accumulation of phytoplankton and POC during all seasons in the marginal ice zone. Temporal changes in solar radiation also strongly affected primary production in open water at the ice edge, particularly between winter and spring. In addition, biomass accumulation was affected by the length of time the water column was uncovered by ice because specific growth rates of antarctic phytoplankton are low (ca 0.4 doublings $\mathrm{d}^{-1}$ ) (Nelson et al. 1987).

During autumn, the highest chlorophyll concentrations occurred at the seaward edge of the marginal ice zone, probably because these waters had been illuminated longer than water recently uncovered near the ice edge. Chlorophyll concentrations also were much higher on the southern transect. Satellite images indicate this may have been the northern edge of a large ice-edge bloom (Comiso et al. 1990). POC maxima occurred in the upper mixed layer, but chlorophyll did not, contrary to previous ice-edge studies (Smith \& Nelson 1985, Nelson et al. 1987). This suggests that some additional factor, such as microand macrozooplankton grazing, may have been important in controlling the standing stock of phytoplankton in this season (Garrison \& Buck 1989b, Nelson et al. 1989).

During winter, chlorophyll distribution was relatively uniform and the highest concentrations occurred in the stratified mixed layer near the ice edge. Chlorophyll concentrations were very low, although concentrations in open water increased between the 2 phases of the field program as a consequence of the increasing amount of incident light between July and August. In spite of complex hydrographic conditions in the study area in winter, chlorophyll showed little variability along the ice edge.

Phytoplankton biomass in spring was the highest of the 3 seasons studied. Within the study area, chlorophyll exhibited a complex spatial distribution with maxima in the mixed layer. Satellite imagery indicated that the highest concentration on the western transect adjacent to the ice margin was associated with a large bloom west of our study area (Nelson et al. 1987). A second, lower biomass concentration was located at the front between Drake Passage water and the Weddell-Scotia Confluence at $59^{\circ} \mathrm{S}$. Although suffi- 
cient stratification occurred all along the ice margin to promote a phytoplankton bloom, substantial phytoplankton biomass was observed only in the western region in Weddell-Scotia Confluence water. Nelson et al. (1987) hypothesized that Weddell Sea water under the ice and to the north on the eastern side of the study area was in an earlier stage of bloom development and only recently had become uncovered by ice.

Distribution of krill. Correlation analyses and spatial distributions of variables did not indicate that physical and chemical factors directly affected the distribution of Euphausia superba in the marginal ice zone. Laboratory experiments have demonstrated that krill are well adapted to the extreme conditions of the Southern Ocean. In one such study, $60 \%$ of the krill survived temperatures down to $-4{ }^{\circ} \mathrm{C}$ and salinity of $69 \%$ (Aarset \& Torres 1989), conditions similar to those experienced in pack ice (Garrison 1991). In our study, the distribution of krill in relation to seawater temperature was variable. In autumn, the densest concentrations of krill were observed in crevices in ice floes, where temperatures were colder $\left(<-1.8^{\circ} \mathrm{C}\right)$ than those of the underlying water column. In autumn and spring, mature adults showed a tendency to be in warmer open water, but in winter, the largest concentrations of all life history stages were just under the ice edge in $-1.8^{\circ} \mathrm{C}$ water. No relationship between salinity and krill distribution was observed.

Our sampling regime did not detect increased concentrations of krill in eddies or currents during winter and spring although retention by eddies has been suggested as a mechanism giving rise to the large concentrations of krill observed in the Scotia Sea in summer (Priddle et al. 1988). Nor did we find krill concentrated along the shelf slope near the South Orkney Islands in winter where they are often found in preference to deeper water in summer (Stein \& Rakusa-Suszczewski 1984, Ichii 1990). Light intensity also did not affect the vertical distribution of krill since day and night depths of krill were similar between under-ice and open-water habitats in all 3 seasons.

In autumn, the highest acoustic biomass concentration occurred at the outer seaward extent of the southern transect in the vicinity of the chlorophyll maximum, and the vertical distribution of acoustic biomass was similar to the depth range of high POC concentrations. Acoustic biomass, however, was not correlated with food supply, possibly for several reasons. On a large scale, food supply should be greater in the marginal ice zone than in water outside the influence of ice melt, but within the marginal ice zone, the distribution of food is very patchy. At individual sampling stations a positive correlation (high krill vs high food condition) could represent krill just having located a patch of food, whereas a negative correlation (high krill vs low food condition) could represent either recent depletion from grazing or krill moving through a low-food area. If data are collected from some stations with positive correlations and some with negative correlations, then no overall correlation from the sampling area between food concentration and krill biomass would be expected. The lack of correlation also could be due to the fact that krill were dispersed, perhaps in response to low food concentrations and seasonal physiological changes. In autumn, krill reduced their metabolism (J. Torres pers. comm.) and adults sexually regressed, thus limiting their food requirements. Phaeopigment, the chlorophyll degradation product of feeding, also was a poor indicator of acoustic biomass. Krill release large fecal pellets that sink rapidly out of the water column. Phaeopigments sampled in the surface layer were probably from microzooplankton grazing and may not be related to krill distribution.

Importance of food availability. On a vertical scale, all stages and sexes of krill were strongly correlated with food distribution. In all 3 seasons, krill occurred primarily within the depth range of the maximum food concentrations in the upper $100 \mathrm{~m}$ of the water column. Even in winter, krill remained in the surface mixed layer in contrast to many other large metazoan grazers and fish which overwintered deep in the water column (T. Hopkins \& J. Torres unpubl.). On a horizontal scale, local distributions were too variable to reveal an association between food and krill. Nevertheless, mesoscale distributions and knowledge about the behavior of different stages of krill indicate that food availability can explain in part the seasonal variability in spatial patterns of Euphausia superba in the marginal ice zone. The influence of food supply is more clearly demonstrated by average seasonal trends. Therefore, the mean concentration of chlorophyll $a$ and POC was calculated for ice floes, ice-covered, and

\begin{tabular}{|ccccc}
\hline & $\frac{\mathrm{Chla}}{2-8}$ \\
$\frac{\mathrm{Chl} \mathrm{a}}{0.09}$ & $\frac{\mathrm{POC}}{32.2}$ & AUTUMN & $\frac{\mathrm{Chla}}{0.33}$ & $\frac{P \text { WOC }}{52.8}$ \\
0.10 & 79.1 & WINTER & 0.15 & 67.5 \\
0.24 & 57.2 & SPRING & 2.69 & 105.3
\end{tabular}

Fig. 21. Seasonal availability of food for Euphausia superba in ice floes and ice-covered and open-water habitats in the marginal ice zone. Water-column chlorophyll a $(\mathrm{Chl} \mathrm{a}, \mathrm{mg}$ $\mathrm{m}^{-3}$ ) and particulate organic carbon (POC, $\mathrm{mg} \mathrm{m}^{-3}$ ) are means calculated from values between 0 and $100 \mathrm{~m}$ from all stations within each habitat. Chlorophyll a concentrations in the ice (top left) are the range of seasonal means from the bottom sections of ice cores in first-year ice. (Water-column data, W. Smith, Jr, unpubl,; ice data, Garrison \& Buck 1989a and D. Garrison unpubl.) 
open-water habitats to determine the location of maximum food resources available to grazers in autumn, winter, and spring (Fig. 21).

Seasonal changes of phytoplankton biomass were most pronounced in open water. Mean chlorophyll concentrations were highest during the spring bloom and lowest in winter. Also, there were clear spatial gradients in chlorophyll between under-ice and openwater habitats in autumn and spring, but not in winter (Fig. 21). Mean chlorophyll was higher in open water than under the pack ice in autumn $(t$-test, $p<0.001)$ and in spring ( $\mathrm{p}<0.001)$, but not significantly different in winter $(\mathrm{p}=0.05)$. POC concentrations showed a slightly different pattern, and unlike chlorophyll, increased from autumn to winter (Fig. 21). Although POC, like chlorophyll, was significantly higher in open water than under the ice in autumn $(t$-test, $\mathrm{p}<0.001)$ and spring ( $\mathrm{p}<0.001)$, it was higher under the pack ice in winter $(p=0.022)$. This difference suggests that ice may act as a source for non-phytoplankton POC and that this input only can be detected during periods of low phytoplankton biomass and growth. POC concentrations may ameliorate the affect of low chlorophyll concentrations on grazers in winter. In contrast to the water column, seasonal changes in food availability were not as pronounced in the pack ice. Chlorophyll concentrations in sea ice consistently were an order of magnitude higher than in the underlying water column and, therefore, a better source of food than that in open water, particularly in autumn and winter. The average seasonal concentration of POC in the ice is not available; however, POC can be very high in the ice (up to

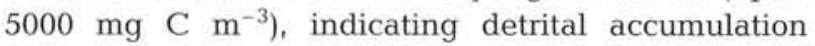
(D. Garrison pers. comm.).

In all seasons, the spatial distributions of male and female krill were similar within a given maturity stage, but the distributions of maturity stages differed in relation to food supply. In autumn, a small percentage of the adult population was still spawning. These individuals, which have a high energetic demand for reproduction, were collected only at the ice edge in open water where food concentrations (and temperature) were higher than under the ice. Unfortunately, Tucker trawls did not sample in the vicinity of the chlorophyll maximum on the southern transect (Fig. 2C), so it is not known if mature adults occurred in this area as well. In contrast, immature adults were found both under the ice and in open water.

In spring, maturing adults again were concentrated in open water in a large phytoplankton bloom, as were immature adults, although gut contents of predators suggest some adults also occurred under the ice. Another spring ice-edge study (Schalk 1990) found maturing adults with higher respiration levels, and therefore greater food requirements, primarily in open water, and immatures ones, with lower respiration levels, under the ice. This suggests that the distribution of spawning adults in autumn and maturing adults in spring is a function of their energetic demands.

The horizontal distribution of adults was different in winter from that in autumn and spring, but the winter distribution also may be related to food availability. During winter, all adults were immature and had a reduced metabolism (J. Torres pers. comm.). Despite low in situ chlorophyll concentrations, almost all individuals had light-green-colored guts, indicating some herbivorous feeding, albeit at low rates (K. Daly unpubl.). In addition to phytoplankton, most gut contents of adults also contained tintinnids and dinoflagellates. The largest concentrations of adults were in the water column near the ice edge where POC concentrations were higher than in open water. The dynamic action of the ice, by concentrating cells during freezing events and releasing them during melting events, may have provided a concentrated localized food source that was not available in open water.

Adults may not need to eat to survive overwintering (Ikeda \& Dixon 1982b), but additional nutrition must influence their condition and perhaps the timing of rematuration in the spring. The ovary in many females appeared to be maturing while the thelycum, the structure where males attach spermatophores, remained immature. In midwinter, some ovaries extended almost to the abdomen, although the eggs were still round and small (K. Daly unpubl.). Overwintering adults also benefitted from reduced competition for the few available food resources because other large metazoan grazers were in low abundance or overwintering deep in the water column (T. Hopkins unpubl.).

In all 3 seasons, the distribution and behavior of larval and small juvenile krill were different from those of large krill. Small krill were more abundant under the pack ice and on the undersurface of ice floes than in open water. Divers observed larvae and juveniles feeding on sea ice biota in brine channels and crevices of ice floes where chlorophyll concentrations were higher than in the underlying water. During this study, only larvae and juveniles, 5 to $25 \mathrm{~mm}$ in length, were collected from ice floes. Apparently larval krill can adapt to scraping food from ice surfaces by the time they have developed to furcilia stage 3 , in late summer or fall depending on when they were spawned. During winter, sea ice biota was an important source of food for larval krill (Daly 1990) and even in spring, when food concentrations were high in open water, age- 0 juveniles remained concentrated on the undersurface of ice floes. It is interesting to note that in spring, Schalk (1990) also found that juveniles under the pack ice had a higher respiration activity, and therefore a higher food demand, than did immature adults. 
Importance of predators. As stated above, food availability does not entirely explain the distributions of life history stages or sizes of krill. It is intriguing that only small krill were found feeding on sea ice biota since food concentrations often were higher in ice floes than in the water column, especially in winter. The length-frequency distributions of krill in relation to ice (Figs. 5, 10, \& 15) indicate that sometime during their second year, when they are about $25 \mathrm{~mm}$ long, Euphausia superba changes its habitat from predominately ice to the water column in the marginal ice zone. Other studies have reported adult krill feeding on the undersurface of ice, but only deep in the pack ice or under fast ice (Spiridonov et al. 1985, O'Brien 1987a, Marschall 1988), whereas larvae and juveniles have been reported under ice floes at the ice edge near the Antarctic Peninsula (Guzman 1983, Hamner et al. 1989) and in the Scotia and Weddell Seas (Daly \& Macaulay 1988, Siegel et al. 1990). The abundance of pack-ice predators increases in the marginal ice zone (see Fig. 20); thus predation pressure may be the mechanism separating small and large E. superba at the ice edge.

Euphausia superba is an important food item for many upper-trophic-level consumers. Approximately 36 predators of krill, including seabirds, seals, fish, squid, copepods, an amphipod, a chaetognath, a euphausiid, and a salp, were documented (Erickson 1984, Ainley et al. 1988, Hopkins \& Torres 1989) in our study areas. In addition, minke whales Balaenoptera acutorostrata, which feed primarily on krill in ice-edge regions (Ichii 1990), were relatively abundant. The mean densities of penguins, flying seabirds, seals, and minke whales were 4 times greater in the pack ice than in open water in autumn, 36 times greater in winter, and similar in spring (Erickson 1984, C. Ribic \& D. Ainley unpubl.). As a result, the overall risk of predation in general is greater near pack ice and likely to influence krill distribution and behavior.

Size- and sex-selective predation also might affect spatial patterns and behavior of Euphausia superba. Ice floes provide small krill with protection from predators (Hamner et al. 1989), but the pack ice may not afford as much protection for larger krill. Accumulating evidence suggests that some of the most common pack-ice predators have specific ice-associated feeding behaviors. For example, a crabeater seal Lobodon carcinophagus in captivity repeatedly exhibited a sucking behavior while feeding that would enable it to extract krill from crevices in the ice (Klages \& Cockcroft 1990). Also, in autumn, divers observed a minke whale bumping the undersurface of an ice floe and then skimming underneath it, which might have been a feeding behavior. During our study, crabeater seals preyed exclusively upon large $(>30 \mathrm{~mm})$
E. superba, while penguins and other seabirds ate all sizes of krill, but often selectively fed on large individuals (K. Daly unpubl.). Furthermore, male E. superba were dominant in diets of most seabirds in autumn and spring (Ainley et al. 1988) in spite of similar female and male size and spatial distributions. Minke whales also have been reported to feed primarily on large krill (Ichii 1990).

Behavior of krill. All life history stages of krill are capable of foraging and predator avoidance behaviors (Hamner 1984, Hamner et al. 1989) and large krill are capable of swimming long distances (Kanda et al. 1982). Hence, mitigation also can be expected to influence the distribution of krill.

In our study, Euphausia superba exhibited a variety of strategies to survive in a heterogeneous environment. Behavior associated with ice differed from that in the water column. Small krill formed dense concentrations under ice floes while foraging for food or evading predators. In the water column, krill generally were widely dispersed in all 3 seasons but some swarms occurred in winter and a greater number were present in spring. Krill also were concentrated in layers in spring. Swarms were detected during both day and night and no vertical migration of either swarms or dispersed krill was seen. Swarms were composed primarily of one life history stage (i.e. larvae, juveniles, or immature adults), and therefore the size of individuals in a swarm was similar. This is typical of krill swarms and is probably due to a sorting process based on size-dependent swimming speeds (Hamner et al. 1983).

Factors influencing swarm formation. Spatial and seasonal changes in krill behavior may be explained as a response to predictable trends in food and planktivory. Optimal behavior theory predicts that foragers should maximize their feeding rate while minimizing the risk of predation (Sih 1980), 2 factors commonly invoked to explain selective advantages to individuals in swarms. Most models developed to explain swarming behavior in Euphausia superba have focused on feeding as the proximate cause or motivating factor for formation, maintenance, and dispersal of swarms (reviewed in Miller \& Hampton 1989). For example, one model predicts that krill should be dispersed under low food conditions, particularly in winter (Everson \& Ward 1980), as was found in a winter survey near South Georgia (Morris \& Priddle 1984). None of these models considered predation. Yet, in the present study, swarming was observed in winter when chlorophyll concentrations were very low, concomitant with predator densities that were an order of magnitude greater than during autumn or spring (C. Ribic \& D. Ainley unpubl.). Winter swarms also were documented during another ice-edge study near the 
Antarctic Peninsula in an area characterized by low chlorophyll concentrations (Brightman \& Smith 1989) and actively foraging predators (Fraser et al. 1989).

* We suggest that the need for food to maintain metabolic activity and predation pressure are the underlying mechanisms influencing the formation of swarms. If these 2 factors are the primary motivating factors in swarming, then under low food (or low food demand) and low predator conditions, krill would be expected to be dispersed, while under conditions of either high food (or high food demand) or predators, or both, krill would be expected to exhibit swarming behavior. This simple, conceptual model is in accordance with the observed spatial and seasonal changes in densities of food and predators and in behavior of krill during this study. Adult Euphausia superba need less food when their metabolic rate is reduced, hence foraging may not be as strong a motivating factor in forming swarms during autumn and winter as during spring. However, even though adult krill may not need to acquire food to survive overwintering, they do need to avoid being eaten by predators. Consequently, in autumn (low food, low food demand, and low predators) only one swarm was detected and in winter (low food, low food demand, and high predators) krill formed swarms. Swarming under the pack ice in spring under conditions of low food (food demand unknown) and increased predator density (Fig. 20) provides further evidence that predation pressure may induce the formation of swarms.

\section{Role of sea ice in the ecology of krill}

Sea ice strongly influences the antarctic ecosystem because its seasonal advance and retreat dominates physical and biological processes in much of the Southern Ocean. In the following discussion, the results of our study are integrated with information from other laboratory experiments and field surveys to explore the mechanistic links between sea ice and the behavior of Euphausia superba, particularly from autumn to spring.

The area of the Southern Ocean inhabited by krill that is influenced by sea ice depends on the seasonal and areal extent of ice cover. High-latitude waters are ice covered for most of the year, whereas lower latitude waters are only ice covered for a few months of the year. At its maximum extent in winter, pack ice covers most of the regions in the Southern Ocean inhabited by Euphausia superba. As the melting ice retreats in spring and summer, the impact of the marginal ice zone is transient in any particular location. However, the region of vertical stability and enhanced phytoplankton biomass may extend $250 \mathrm{~km}$ or more from the ice edge and may last up to $2 \mathrm{mo}$ at any particular location, depending on the rate of ice retreat (Smith \& Nelson 1986). Clearly, phytoplankton blooms in the marginal ice zone can impact large areas of the Southern Ocean for significant periods of time.

Importance of ice-edge blooms. The enhanced biomass and predictability of food resources in ice-edge blooms is important for reproduction in adult Euphausia superba. Spawning females usually are found from late spring to late summer, suggesting that reproduction is food limited during the rest of the year. Ross \& Quetin (1986) estimated that females need food concentrations of 1 to $5 \mathrm{mg}$ chlorophyll $\mathrm{m}^{-3}$ to support egg production. In our study, however, some adults were still spawning in autumn when the average chlorophyll concentration was $<1 \mathrm{mg} \mathrm{m}^{-3}$. Several explanations are possible: either food estimates for egg production are high, these adults obtained food from other sources, or food conditions in this area had recently changed. Nevertheless, phytoplankton biomass (1 to $30 \mathrm{mg}$ chlorophyll $\mathrm{m}^{-3}$ ) and primary production in blooms (Smith \& Nelson 1986, Nelson et al. 1987) are generally high enough to sustain reproduction.

The enhanced biomass and predictability of food resources in the marginal ice zone also are important to first-feeding larvae (calytopsis 1). In the laboratory, C1 larvae did not survive unless they aquired food within 10 to $14 \mathrm{~d}$, and food concentrations $>0.5 \mathrm{mg}$ chlorophyll $\mathrm{m}^{-3}$ were needed for larvae to obtain enough food to satisfy their daily metabolic requirements (Ross \& Quetin 1989). In our autumn study site, chlorophyll levels generally were $<0.5 \mathrm{mg} \mathrm{m}^{-3}$; however, the densest concentrations of larvae in open water occurred in the vicinity of the highest chlorophyll concentrations $\left(0.5\right.$ to $\left.1.8 \mathrm{mg} \mathrm{m}^{-3}\right)$, distant from the ice margin. The average chlorophyll concentration under the ice was $<0.1 \mathrm{mg} \mathrm{m}^{-3}$. Thus, $\mathrm{C} 1$ larvae under the ice in autumn may not survive unless they are able to utilize food sources in addition to phytoplankton.

The quality of food in ice-edge blooms may be important for reproduction in adults and survival of calytopis larvae. Relatively large diatoms dominate bloom assemblages (Fryxell \& Kendrick 1988), while nano- and picoplankton may dominate the phytoplankton for most other areas of the Southern Ocean (Weber \& El-Sayed 1987). Euphausia superba are more effective at filtering large cells (Quetin \& Ross 1985, Ishii 1986) than small ones and field studies have shown that grazing by large concentrations of krill effectively removed large cells and changed mesoscale phytoplankton species composition (HolmHansen \& Huntley 1984). Further, an experimental study indicated that first-feeding larvae developed normally when fed diatoms but did not survive when fed a small flagellate (Ross et al. 1988). 
Given that food availability is an important mechanism governing krill distribution and krill are capable of foraging over long distances, it seems reasonable to assume that maturing and spawning adults follow the southward progression of ice-edge blooms. In fact, the seasonal location of whales and trawlers indicates that krill primarily are concentrated near the receding ice edge throughout spring (Ichii 1990), and additional evidence is provided by the distribution of adults and larvae in our autumn study area. In March, spawning adults were found only near the ice edge in open water, while large concentrations of C1 larvae were found about $300 \mathrm{~km}$ from the ice edge in the vicinity of the highest chlorophyll concentration. After females spawn, the eggs sink and hatching occurs between 850 and $1850 \mathrm{~m}$; after molting through several stages, C1 larvae ascend to the surface about $30 \mathrm{~d}$ after spawning (Hempel \& Hempel 1986). The predominance of C1 larvae concomitant with few older larval stages suggests that spawning did not begin until February in this region. Satellite images showed that the ice edge in this area had receded about $300 \mathrm{~km}$ in the previous month (Comiso et al. 1990). Furthermore, currents in the study area were barely detectable even at hatching depths, based on data from a satellite-tracked buoy deployed on an ice floe and the dynamic topography of the surface relative to $1500 \mathrm{~dB}$ (Nelson et al. 1989). Hence, it is likely that $\mathrm{C} 1$ larvae surfaced near where they were spawned and therefore may be evidence of continuous spawning by adults following a receding ice edge. The concentrations of C1 larvae under the ice in autumn are an enigma, as dispersal by currents is unlikely. Perhaps spawning stocks were also under the pack ice earlier in the season.

It seems unlikely that many krill in the Scotia Sea follow the retreating pack ice into the central Weddell Sea since large concentrations of krill typically are fished north of the South Orkney Islands in summer (Ichii 1990). Nevertheless, if adults follow the ice edge, then larvae will arrive at the surface spatially removed from adults, resulting in reduced competition for food resources and diminished cannibalism by adults. Because of the low accumulation rates of polar phytoplankton, biomass maxima often occur well seaward of the ice edge (Nelson et al. 1989), ensuring small larvae an adequate food supply.

Importance of sea ice biota. In addition to utilizing ice-edge blooms in autumn and spring, Euphausia superba also has specific foraging and predatoravoidance behavior patterns associated with the seasonal pack ice that are important for overwintering survival. Ice algae can bloom late in autumn (Hoshiai 1985) and early in spring, well before water-column ice-edge blooms begin (Garrison \& Buck 1989a), and concentrations of ice algae are common in the Weddell Sea pack ice in winter (Ackley et al. 1990). Thus, sea ice biota provides a prevalent and concentrated food source during an otherwise unproductive time of year.

Larvae, unlike adults, cannot survive overwintering without food (Quetin \& Ross 1991); hence, the extent of ice cover over nursery areas adjacent to the Antarctic Peninsula and in the Weddell-Scotia Confluence is particularly important. At our winter study site, the ice edge extended almost to $58^{\circ} \mathrm{S}$ in the Scotia Sea, a latitude that receives some irradiance even in winter. The average chlorophyll concentration in sea ice $17 \mathrm{mg}$ $\mathrm{m}^{-3}$; D. Garrison unpubl.) was much higher than that in the underlying water. It is not known how much of the chlorophyll in sea ice is available to krill scraping the ice surface. Larval krill that fed on sea ice biota, however, continued to develop and grow during winter (Daly 1990), in contrast to larvae that stopped development when held in ambient winter seawater conditions ( $<0.2 \mathrm{mg}$ chlorophyll $\mathrm{a} \mathrm{m}^{-3}$ ) at Palmer Station (Ross et al. 1987). Thus, the availability of food in sea ice over nursery areas has significant implications for both the survival and recruitment of Euphausia superba.

In contrast to larvae, adult krill have a number of alternative overwintering strategies. Adult krill do not build up enough lipid reserves (Clarke 1984) to survive starvation periods as do many other zooplankton. Instead, their primary overwintering strategy is to lower their metabolic rate and use their own lipids and proteins if food cannot be obtained (Quetin \& Ross 1991). During our study, adults were concentrated in the upper $100 \mathrm{~m}$ of the water column near the ice edge and were feeding omnivorously at low rates. Overwintering behavior is different elsewhere. Near South Georgia, over shelf and deep-water areas, few krill were feeding and the majority were deeper (>250 m) than the depth range of the phytoplankton biomass (Morris \& Priddle 1984). Near the Antarctic continent, in shallow water $(40 \mathrm{~m})$ under fast ice, krill ingested detritus off the sea floor (Kawaguchi et al. 1986). Under the Weddell Sea pack ice in deep water, few krill were found in the water column; they were concentrated on the undersurfaces of ice floes and feeding on sea ice biota (Marschall 1988). Obviously, Euphausia superba has the capacity to vary its overwintering feeding behavior depending on the environment and food availablility.

In our study, adults were concentrated near the ice edge in winter. However, other studies suggest that most adults migrate south under the pack ice and feed on ice biota during winter because few krill are collected in open water in winter (Mackintosh 1972, Siegel 1988) and many adults were seen feeding on sea ice biota throughout the Weddell Sea in winter 
(Marschall 1988). If adults migrate deep into the pack ice, competition with larvae under ice floes in nursery areas near the ice edge will be reduced.

Implications of density. Krill density was generally low in the marginal ice zone, even though our sampling occurred in different years $(1983,1986$, 1988), at several locations (Scotia Sea, Weddell-Scotia Confluence, northern Weddell Sea) and in different seasons (autumn, winter, spring). The results of another spring ice-edge study (Siegel et al. 1990), in a similar location but a few years later, also imply that interannual variability may be small in the marginal ice zone. In comparison, high abundance and high variability in the distribution of krill due to swarming behavior are common along island and continental shelf slopes in summer (Macaulay et al. 1984, Ichii 1990).

Abundances in the marginal ice zone may be low in the water column but the number of krill inhabiting the undersurface of ice floes is potentially high. If the latter component of the population was adequately assessed, biomass estimates in the marginal ice zone would increase. The estimated concentration of juveniles (3000 ind. $\mathrm{m}^{-2}$ ) under an ice floe in autumn is higher than those previously reported under ice floes deep in the pack ice (maximum 1500 ind. $\mathrm{m}^{-2}$; Marschall 1988), and is similar to densities of swarms in the water column in open water (Hamner et al. 1983).

Moreover, the difference in areal extent of ice edge and shelf regions may be important in governing distribution patterns of krill. The area influenced by the ice margin is very large compared with that of shelf breaks or eddies near islands and the continent. Krill may have to concentrate in shelf regions but not along ice edges to compete for available food. While densities in any given location at the ice edge are low, the total population of krill supported by ice-edge blooms may be greater than that supported by shallow shelf blooms in summer. Certainly, sea ice biota are the most abundant source of food in winter for krill inhabiting water covered by sea ice.

\section{CONCLUSIONS}

In the marginal ice zone, physical-biological interactions affect the distribution and behavior of Euphausia superba. The correlation analyses of abiotic and biotic factors did not demonstrate important mechanistic links, perhaps because the spatial scales of sampling were inadequate and owing to differences in food requirements by the different life history stages of krill. On large spatial and temporal scales, it is clear that physical processes strongly impact krill, because these processes control the extent of ice cover, the magnitude and location of food, and the presence of pack-ice predators. However, physical factors do not appear to directly affect krill. Instead, the seasonal distribution of life history stages and the behavior of krill are a function of food demand and risk of predation. These 2 factors also are believed to be the proximate cause for the formation and maintenance of krill swarms during autumn, winter, and spring.

Our study showed that the seasonal pack ice plays an integral part in the life history of Euphausia superba. Ice-edge blooms provide reproductive adults and first-feeding larvae with higher food concentrations than are found in open water uninfluenced by ice melt, and thus may affect reproductive success and the initial strength of a year class. The variability in the distribution of life history stages and in the complexity of behavior in krill is expected for a highly mobile animal foraging for a temporally and spatially episodic food supply, while avoiding predators. Perhaps the most important role of the pack ice is as a nursery area for young krill, providing protection from predators and a vast food resource from autumn to spring. For this reason, and given the possibility of global warming and the influence of climate on the extent of ice cover in polar regions (Zwally et al. 1983b), it is of fundamental importance to further elucidate the role of seasonal sea ice in the antarctic ecosystem.

Predicting population variability is essential for understanding food-web dynamics and exploited fisheries, yet little is known about stabilizing mechanisms in marine systems. From this study, it is apparent that sea ice biota in the seasonal pack ice acts as a buffer for the extreme seasonal oscillation of food availability in the water column, thereby providing a stabilizing mechanism for the persistence of populations of Euphausia superba. This relationship is particularly important in the Weddell-Scotia Sea region, one of the world's largest sea ice environments.

Acknowledgements. We thank the personnel aboard the USCGC 'Westwind' and 'Glacier' and the RV 'Polar Duke', and our AMERIEZ colleagues for their assistance with data collection. Drs D. Ainley, E. Brinton, D. Garrison, T. Hopkins, R. Muench, C. Ribic, W. O. Smith, Jr, and J. Torres generously provided samples or unpublished data that were important to the interpretation of results. We are grateful to Drs R. Francis and W. O. Smith, Jr, and 3 anonymous reviewers for helpful comments on the manuscript, to Dr D. Henry for editing, and to L. Sylvester for preparing the figures. This research was supported by National Science Foundation grants DPP 82 18784 and DPP 84-20215 to M. Macaulay and B. Frost. This is Contribution no. 1903 from the School of Oceanography, University of Washington. 


\section{LITERATURE CITED}

Aarset, A. V., Torres, J. J. (1989). Cold resistance and metabolic responses to salinity variations in the amphipod Eusirus antarcticus and the krill Euphausia superba. Polar Biol. 9: 491-497

Ackley, S, F, Dieckmann, G., Lange, M., McGrew, S. (1990). Winter-spring comparisons of algal standing crop in antarctic sea ice. Eos 71: 80

Ainley, D. G., Fraser, W. R., Daly, K. L. (1988). Effects of pack ice on the composition of micronektonic communities in the Weddell Sea. In: Sahrhage, D. (ed.) Antarctic ocean and resources variability. Springer-Verlag, Berlin, p. $140-146$

Amos, A. F. (1984). Distribution of krill (Euphausia superba) and the hydrography of the Southern Ocean: large-scale processes. J. crust. Biol. 4 (Spec. No, 1): 306-329

Bradstreet, M. S., Cross, W. E. (1982). Trophic relationships at high arctic ice edges. Arctic 35: 1-12

Brightman, R. I., Smith, W. O. Jr (1989). Photosynthesisirradiance relationships of antarctic phytoplankton during austral winter. Mar. Ecol. Prog. Ser. 53: 143-151

Brinton, E. (1984). Observations of plankton organisms obtained by bongo nets during the November-December 1983 ice-edge investigations. Antarctic J. U.S. 19: 113-115

Brinton, E., Loeb, V. J., Macaulay, M. C., Shulenberger, E. (1987). Variability of Euphausia superba populations near Elephant Island and the South Shetlands: 1981 vs. 1984. Polar Biol. 7: 345-362

Brinton, E., Townsend, A. W. (1984). Regional relationships between development and growth in larvae of antarctic krill, Euphausia superba, from field samples. J. crust. Biol. 4 (Spec. No. 1): $224-246$

Clarke, A. (1984). Lipid content and composition of antarctic krill, Euphausia superba Dana. J. crust. Biol. 4 (Spec. No. 1): $285-294$

Clarke, D. B., Ackley, S. F. (1984). Sea ice structure and biological activity in the antarctic marginal ice zone. J. geophys. Res. 89: 2087-2095

Comiso, J. C., Maynard, N. G., Smith, W. O. Jr, Sullivan, C. W. (1990). Satellite ocean color studies of antarctic ice edges in summer and autumn. J. geophys. Res. 95: 9481-9496

Croxall, J. P., Prince, P. A., Ricketts, C. (1985). Relationship between prey life-cycles and the extent, nature and timing of seal and seabird predation in the Scotia Sea. In: Siegfreid, W. R., Condy, P. R., Laws, R. M. (eds.) Antarctic nutrient cycles and food webs. Springer-Verlag, Berlin, p. $516-533$

Daly, K. L. (1990), Overwintering development, growth, and feeding of larval Euphausia superba in the antarctic marginal ice zone. Limnol. Oceanogr. 35: 1564-1576

Daly, K. L., Macaulay, M. C. (1988). Abundance and distribution of krill in the ice edge zone of the Weddell Sea, austral spring 1983. Deep Sea Res. 35: 21-41

Dieckmann, G. (1987). High phytoplankton biomass at the advancing ice edge in the northern Weddell Sea in winter. Eos 68: 1765

Erickson, A. W. (1984). Aerial census of seals, whales, and penguins in the pack ice of the northwestern Weddell Sea, November 1983. Antarctic J. U.S. 19: 121-124

Everson, I., Ward, P. (1980). Aspects of Scotia Sea zooplankton. Biol. J. Linn. Soc. 14: 93-101

Fevolden, S. E., Schneppenheim, R. (1988). Genetic population structure of Euphausia superba Dana in the Atlantic sector of the Southern Ocean as demonstrated by different electrophoretic techniques. Polar Biol. 9: 1-8

Fraser, F. C. (1936). On the development and distribution of the young stages of krill (Euphausia superba). 'Discovery' Rep. 14: 1-192

Fraser, W. R., Ainley, D. G. (1986). Ice edges and seabird occurrence in Antarctica. BioSci. 36: 258-263

Fraser, W. R., Pitman, R. L., Ainley, D. G. (1989). Seabird and fur seal responses to vertically migrating winter krill swarms in Antarctica. Polar Biol. 10: 37-41

Fryxell, G. A., Kendrick, G. A. (1988). Austral spring microalgae across the Weddell Sea ice edge: spatial relationships found along a northward transect during AMERIEZ 83. Deep Sea Res. 35: 1-20

Garrison, D. L. (1991). Antarctic sea ice biota. Am. Zool. 31: $17-33$

Garrison, D. L., Buck, K. R. (1989a). The biota of antarctic pack ice in the Weddell Sea and Antarctic Peninsula regions. Polar Biol. 10: 211-219

Garrison, D. L., Buck, K. R. (1989b). Protozooplankton in the Weddell Sea, Antarctica: abundance and distribution in the ice-edge zone. Polar Biol. 9: 341-351

Gliwicz, Z. M., Pijanowska, J. (1990). The role of predation in zooplankton succession. In: Sommer, U. (ed.) Plankton ecology. Springer-Verlag, Berlin, p. 253-296

Guzman, O. (1983). Distribution and abundance of antarctic krill (Euphausia superba) in the Bransfield Strait. In Schnack, S. B. (ed.) On the biology of krill Euphausia superba. Alfred-Wegener-Institut für Polar- und Meeresforschung, Bremerhaven, p. 169-190

Hamner, W. M. (1984). Aspects of schooling in Euphausia superba. J. crust. Biol. 4 (Spec. No. 1): 67-74

Hamner, W. M., Hamner, P. P., Obst, B. S., Carleton, J. H. (1989). Field observations on the ontogeny of schooling of Euphausia superba furciliae and its relationship to ice in antarctic waters. Limnol. Oceanogr. 34: 451-456

Hamner, W. M., Hamner, P. P., Strand, S. W., Gilmer, R. W. (1983). Behavior of antarctic krill, Euphausia superba: chemoreception, feeding, schooling, and molting. Science 220: 433-435

Hempel, I., Hempel, G. (1986). Field observations on the developmental ascent of larval Euphausia superba (Crustacea). Polar Biol. 6: 121-126

Heywood, R. B., Everson, I., Priddle, J. (1985). The absence of krill from the South Georgia zone, winter 1983. Deep Sea Res. 32: 369-378

Holm-Hansen. O., Huntley, M. (1984). Feeding requirements of krill in relation to food sources. J. crust. Biol. 4 (Spec. No. 1): $156-173$

Holm-Hansen, O., Mitchell, B. G., Hewes, C. D., Karl, D. M. (1989). Phytoplankton blooms in the vicinity of Palmer Station, Antarctica. Polar Biol. 10: 49-57

Hopkins, T. L., Torres, J. J. (1989). Midwater food web in the vicinity of a marginal ice zone in the western Weddell Sea. Deep Sea Res. 36: 543-560

Hoshiai, T. (1985). Autumnal proliferation of ice-algae in antarctic sea-ice. In: Siegfried, W. R., Condy, P. R., Laws, R. M. (eds.) Antarctic nutrient cycles and food webs. Springer-Verlag, Berlin, p. 89-92

Hosie, G. W., Stolp, M. (1989). Krill and zooplankton in the western Prydz Bay region, September-November 1985 Proc. NIPR Symp. Polar Biol. 2: 34-45

Husby, D. M., Muench, R. D. (1988). Hydrographic observations in the northwestern Weddell Sea marginal ice zone during March 1986. NOAA Tech, Memo. NOAA-TMNMFS-SWFC-106, NOAA/NMFS, Monterey, CA, p. 1-33

Husby, D. M., Muench, R. D., Gunn, J. T. (1989). Oceanographic observations in the Scotia Sea marginal ice zone June-August 1988. NOAA Tech. Memo. NOAA-TMNMFS-SWFC-127, NOAA/NMFS, Monterey, CA, p. 1-64 
Ichii, T. (1990). Distribution of antarctic krill concentrations exploited by Japanese krill trawlers and minke whales. In: Proc. NIPR Symp. Polar Biol., No. 3. National Institute of Polar Research, Tokyo, p. 36-56

Ikeda, T. (1984). Development of the larvae of the antarctic krill (Euphausia superba Dana) observed in the laboratory. J, exp. mar. Biol. Ecol. 75: 107-117

Ikeda, T., Dixon, P. (1982a). Observations on moulting in antarctic krill (Euphausia superba Dana). Aust. J. mar. Freshwat. Res. 33: 71-76

Ikeda, T., Dixon, P. (1982b). Body shrinkage as a possible over-wintering mechanism of the antarctic krill, Euphausia superba Dana. J. exp. mar. Biol. Ecol. 62: 143-151

Ikeda, T., Kirkwood, R. (1989). Metabolism and body composition of two euphausiids (Euphausia superba and E. crystallorophias) collected from under the pack-ice off Enderby Land, Antarctica. Mar. Biol. 100: 301-308

Ikeda, T., Thomas, P. G. (1987). Moulting interval and growth of juvenile antarctic krill (Euphausia superba) fed different concentrations of the diatom Phaeodactylum tricornutum in the laboratory. Polar Biol. 7: 339-343

Ishii, H. (1986). Feeding behavior of the antarctic krill, Euphausia superba Dana. II. Effects of food condition on particle selectivity. Mem. Natn. Inst. Polar Res. (Spec. Issue) 44: 96-106

Kalinowski, J., Witek, Z. (1985). Scheme for classifying aggregations of antarctic krill. BIOMASS Handb. Ser. 27: 1-12

Kanda, K., Takagi, K., Seki, Y. (1982). Movement of the larger swarms of antarctic krill Euphausia superba population off Enderby Land during 1976 - 1977 season. J. Tokyo Univ. Fish. 68: 25-42

Kawaguchi, K., Ishikawa, S., Matsuda, O. (1986). The overwintering strategy of antarctic krill (Euphausia superba Dana) under the coastal fast ice off the Ongul Islands in Lutzow-Holm Bay, Antarctica. Mem. Natn. Inst. Polar Res. (Spec. Issue) 44:67-85

Klages, N. T. W., Cockcroft, V. G. (1990). Feeding behavior of a captive crabeater seal. Polar Biol. 10: 403-404

Lancraft, T. M., Hopkins, T. L., Torres, J. J., Donnelly, J. (1991). Oceanic micronektonic/macrozooplanktonic community structure and feeding under ice covered Antarctic waters during the winter (AMERIEZ 1988). Polar Biol. 11: $157-167$

Lancraft, T. M., Torres, J. J., Hopkins, T. L. (1989). Micronekton and macrozooplankton in the open waters near antarctic ice edge zones (AMERIEZ 1983 and 1986). Polar Biol. 9: 225-233

Landry, M. R. (1977). A review of important concepts in the trophic organization of pelagic ecosystems. Helgoländer wiss. Meeresunters. 30: 8-17

Laws, R. M. (1985). The ecology of the Southern Ocean. Am. Scient. 73: 26-40

Macaulay, M. C., English, T. S., Mathisen, O. A. (1984). Acoustic characterization of swarms of antarctic krill (Euphausia superba) from Elephant Island and Bransfield Strait. J. crust. Biol. 4 (Spec. Issue No. 1): 16-44

MacDonald, C. M., Williams, R., Adams, M. (1986). Genetic variation and population structure of krill (Euphausia superba Dana) from the Prydz Bay region of antarctic waters. Polar Biol. 6: 233-236

Mackas, D., Denman, K., Abbot, M. (1985). Plankton patchiness: biology in the physical vernacular. Bull. mar. Sci. 37: 652-674

Mackintosh, N. A. (1972). Life cycle of antarctic krill in relation to ice and water conditions. 'Discovery' Rep. 36: 1-94

Mackintosh, N. A. (1973). Distribution of post-larval krill in the Antarctic. 'Discovery' Rep. 36: 95-156
Makarov, R. R., Denys, C. J. (1981). Stages of sexual maturity of Euphausia superba Dana. BIOMASS Handb. Ser. 11: 1-11

Marr, J. W. S. (1962). The natural history and geography of the antarctic krill (Euphausia superba Dana). 'Discovery' Rep. 32: 33-464

Marschall, H-P. (1988). The overwintering strategy of antarctic krill under the pack-ice of the Weddell Sea. Polar Biol. 9: 129-135

McRoy, P. C., Goering, J. J., Shiels, W. E. (1972). Studies of primary production in the eastern Bering Sea. In: Takenouti, A. Y. et al. (eds.) Biological oceanography of the northern north Pacific Ocean. Idemitsu Shoten, Tokyo, p. $199-216$

Miller, D. G. M., Hampton, I. (1989). Biology and ecology of the antarctic krill (Euphausia superba Dana): a review. BIOMASS scient. Ser. 9: 1-166

Morris, D. J., Priddle, J. (1984). Observations on the feeding and moulting of the antarctic krill, Euphausia superba Dana, in winter. Br. Antarct. Surv. Bull. 65: 57-63

Muench, R. D., Gunn, J. T., Husby, D. M. (1990). The Weddell-Scotia Confluence in mid-winter. J. geophys. Res. 95: 18,177-18,190

Muench, R. D., Huber, B. A., Gunn, J. T., Husby, D. M., Mountain, D. G. (1992). The Weddell-Scotia marginal ice zone: physical oceanographic conditions, geographical and seasonal variability. J. mar. Syst. 3: in press

Naganobu, M., Komaki, Y. (1986). Changes in the condition of the surface water and distribution of Euphausia superba Dana between $65^{\circ} \mathrm{E}$ and $75^{\circ} \mathrm{E}$ in the Antarctic Ocean during the pack ice melting season (extended abstract). Mem. Natn. Inst. Polar Res. (Spec. Issue) 40:187-190

Naito, Y., Taniguchi, A., Hamada, E. (1986). Some observations on swarms and mating behavior of antarctic krill (Euphausia superba Dana). Mem. Natn. Inst. Polar Res. (Spec. Issue) 40: 178-182

Nast, F. (1982). The assessment of krill (Euphausia superba Dana) biomass from a net sampling programme. Meeresforsch. 29: 154-165

Nast, F., Gieskes, W. (1986). Phytoplankton observations relative to krill abundance around Elephant Island in November 1983. Arch. FischWiss. 37: 95-106

Nelson, D. M., Smith, W. O. Jr, Gordon, L. I., Huber, B. A. (1987). Spring distributions of density, nutrients and phytoplankton biomass in the ice-edge zone of the Weddell/Scotia Sea. J. geophys. Res. 92: 7181-7190

Nelson, D. M., Smith, W. O. Jr, Muench, R. D., Gordon, L. I., Sullivan, C. W., Husby, D. M. (1989). Particulate matter and nutrient distributions in the ice-edge zone of the Weddell Sea: relationship to hydrography during late summer. Deep Sea Res. 36: 191-209

Nicol, S. (1986). Shape, size and density of daytime surface swarms of the euphausiid Meganyctiphanes norvegica in the Bay of Fundy. J. Plankton Res. 8: 29-39

O'Brien, D. P. (1987a). Direct observations of the behavior of Euphausia superba and Euphausia crystallorophias (Crustacea: Euphausiacea) under pack ice during the antarctic spring of 1985. J. crust. Biol. 7: 437-448

O'Brien, D. P. (1987b). Description of escape responses of krill (Crustacea: Euphausiacea), with particular reference to swarming behavior and the size and proximity of the predator. J. crust. Biol. 7: 449-457

O'Brien, D. P. (1989). Analysis of the internal arrangement of individuals within crustacean aggregations (Euphausiacea, Mysidacea). J, exp. mar. Biol. Ecol. 128: 1-30

Priddle, J., Croxall, J. P., Everson, I., Heywood, R. B., Murphy, E. J., Prince, P. A., Sear, C. B. (1988). Large-scale fluctua- 
tions in distribution and abundance of krill - a discussion of possible causes. In: Sahrhage, D. (ed.) Antarctic Ocean and resources variability. Springer-Verlag, Berlin, p. 169-182

Quetin, L. B., Ross, R. M. (1985). Feeding by antarctic krill, Euphausia superba: Does size matter? In: Siegfried, W. R., Condy, P. R., Laws, R. M. (eds.) Antarctic nutrient cycles and food webs. Springer-Verlag, Berlin, p. 372-377

Quetin, L. B., Ross, R. M. (1991). Behavioral and physiological characteristics of the antarctic krill, Euphausia superba. Am. Zool. 31: 49-63

Rakusa-Suszczewski, S. (1982). Feeding of Euphausia superba under natural conditions. Pol. polar Res. 3: 289-297

Ross, R. M., Quetin, L. B. (1986). How productive are antarctic krill? BioSci. 36: 264-269

Ross, R. M., Quetin, L. B. (1989). Energetic cost to develop to the first feeding stage of Euphausia superba Dana and the effect of delays in food availability. J. exp. mar. Biol. Ecol. 133: 103-127

Ross, R. M., Quetin, L. B., Amsler, M. O., Elias, M. C. (1987). Larval and adult krill, Euphausia superba, 1986 winter observations at Palmer Station. Antarctic J. U.S. 22: 205-206

Ross, R. M., Quetin, L. B., Kirsch, E. (1988). Effect of temperature on developmental times and survival of early larval stages of Euphausia superba Dana. J. exp. mar. Biol. Ecol. 121: $55-71$

Sahrhage, D. (ed.) (1988). Summary and conclusions. In: Antarctic Ocean and resources variability. Springer-Verlag, Berlin, p. 297-300

Sahrhage, D. (1989). Antarctic krill fisheries: potential resources and ecological concerns. In: Caddy, J. F. (ed.) Marine invertebrate fisheries: their assessment and management. John Wiley \& Sons, New York, p. 13-33

Sakshaug, E., Holm-Hansen, O. (1984). Factors governing pelagic production in polar oceans. In: Holm-Hansen, O., Bolis, L., Gilles, R. (eds.) Marine phytoplankton and productivity. Springer-Verlag, Berlin, p. 1-18

Schalk, P.H. (1990). Biological activity in the antarctic zooplankton community. Polar Biol. 10: 405-411

Siegel, V. (1988). A concept of seasonal variation of krill (Euphausia superba) distribution and abundance west of the Antarctic Peninsula. In: Sahrhage, D. (ed.) Antarctic Ocean and resources variability. Springer-Verlag, Berlin, p. $219-230$

Siegel, V., Bergstrom, B., Stromberg, J. O., Schalk, P. H. (1990). Distribution, size frequencies and maturity stages of krill, Euphausia superba, in relation to sea-ice in the northern Weddell Sea. Polar Biol. 10: 549-557

Sih, A. (1980). Optimal behavior: Can foragers balance two conflicting demands? Science 210: 1041-1043

Sissenwine, M. P. (1984). Why do fish populations vary ? In: May, R. M. (ed.) Exploitation of marine communities. Dahlem Konferenzen. Springer-Verlag, Berlin, p. 59-94

Smith, W. O., Nelson, D. M. (1985). Phytoplankton bloom produced by a receding ice edge in the Ross Sea: spatial coherence with the density field. Science 227: 163-166

Smith, W. O. Jr, Nelson, D. M. (1986). Importance of ice edge phytoplankton production in the Southern Ocean. BioSci. 36: $251-257$

Smith, W. O. Jr, Nelson, D. M. (1990). Phytoplankton growth and new production in the Weddell Sea marginal ice zone during austral spring and autumn. Limnol. Oceanogr. 35: 809-821

Smith, W. O. Jr, Sakshaug, E. (1990). Polar phytoplankton. In: Smith, W. O. Jr (ed.) Polar oceanography, Part B, Chemistry, biology, and geology. Academic Press, San Diego, p. 477-525

Spiridonov, V. A., Gruzov, E. N., Pushkin, A. F. (1985), Investigations of schools of antarctic Euphausia superba (Crustacea, Euphausiacea) under the ice. Zool. Zh. 64: $1655-1660$

Steele, J. H., Frost, B. W. (1977). The structure of plankton communities. Phil. Trans. R. Soc. 280: 485-533

Stein, M., Rakusa-Suszczewski, S. (1984). Meso-scale structure of water masses and bottom topography as the basis for krill distribution in the SE Bransfield Strait February-March 1981. Meeresforsch. 30: 73-81

Stepien, J. C. (1982). Zooplankton in the Weddell Sea, October-November 1981. Antarctic J. U.S. 17: 109-111

Strand, S. W., Hamner, W. M. (1990). Schooling behavior of antarctic krill (Euphausia superba) in laboratory aquaria: reactions to chemical and visual stimuli. Mar. Biol. 106: 355-359

Stretch, J. J., Hamner, P. P., Hamner, W. M., Michel, W. C., Cook, J., Sullivan, C. W. (1988). Foraging behavior of antarctic krill Euphausia superba on sea ice micralgae. Mar. Ecol, Prog. Ser, 44: 131-139

Thomas, P. G., Ikeda, T. (1987). Sexual regression, shrinkage, re-maturation and growth of spent female Euphausia superba in the laboratory. Mar. Biol. 95: 357-363

Weber, L. H., El-Sayed, S. Z. (1985). Spatial variability of phytoplankton and the distribution and abundance of krill in the Indian sector of the Southern Ocean. In: Siegfreid, W. R., Condy, P. R., Laws, R. M. (eds.) Antarctic nutrient cycles and food webs. Springer-Verlag, Berlin, p. 284-293

Weber, L. H., El-Sayed, S. Z. (1987). Contributions of the net, nano- and picoplankton to the phytoplankton standing crop and primary productivity in the Southern Ocean. J. Plankton Res. 9: 973-994

Weber, L. H., El-Sayed, S. Z., Hampton, I. (1986). The variance spectra of phytoplankton, krill and water temperature in the Antarctic Ocean south of Africa. Deep Sea Res. 33: 1327-1343

Wilkinson, L. (1989). SYSTAT; the system for statistics. SYSTAT, Inc., Evanston, Illinois

Witek, Z., Kalinowsjki, J., Grelowski, A. (1988). Formation of antarctic krill concentrations in relation to hydrographic processes and social behavior. In: Sahrhage, D. (ed.) Antarctic Ocean and resources variability. Springer-Verlag, Berlin, p. 237-244

Witek, Z., Kalinowski, J., Grelowski, A., Wolnomiejski, N. (1981). Studies of aggregations of krill (Euphausia superba). Meeresforsch. 28: 228-243

Zar, J. H. (1984). Biostatistical analysis. Prentice-Hall, Englewood Cliffs, NJ

Zwally, H. J., Comiso, J. C., Parkinson, C. L., Campbell, W. J., Carsey, F. D., Gloersen, P. (1983a). Antarctic sea ice, 1973-1976: satellite passive-microwave observations. NASA Spec. Publ. 459

Zwally, H. J., Parkinson, C. L., Comiso, J. C. (1983b). Variability of antarctic sea ice and changes in carbon dioxide. Science 220: 1005-1012 